\title{
Green patents, regulatory policies and research network policies
}

\author{
Andrea Fabrizi ${ }^{\mathrm{a}}$, Giulio Guarini ${ }^{\mathrm{b}}$, Valentina Meliciani ${ }^{\mathrm{c},}$ \\ ${ }^{\text {a }}$ Presidenza del Consiglio dei Ministri, Rome, Italy \\ b Tuscia University, Viterbo, Italy \\ ${ }^{\mathrm{c}}$ LUISS University, Rome, Italy
}

\section{A R T I C L E I N F O}

\section{Keywords:}

Green patents

Porter hypothesis

Research networks

Policy mix

\begin{abstract}
A B S T R A C T
The main goal of this paper is to analyse the single and joint impact of regulation policies and research network policies on environmental innovation. Our theoretical framework combines the open eco-innovation mode approach with the Porter Hypothesis, by adapting them to the knowledge production function where green patents are the dependent variable. We focus on the factors that influence the production of green patents as a proxy of new "environmental" knowledge for a panel of European countries over time. We find that both marked-based regulation policies and participation in green European research networks (in particular with universities and public research centres) positively affect environmental innovation. Moreover, the two policy tools have a complementary effect. This suggests that the effectiveness of environmental regulation policies can be increased by combining them with appropriate innovation policies.
\end{abstract}

\section{Introduction}

Environmental Research and Innovation is a cornerstone of the Europe 2020 Strategy, which identifies smart, sustainable and inclusive growth as a means to help the EU develop a resource efficient, greener and more competitive economy while delivering high levels of employment, productivity and social cohesion. As a result, it is expected that at least $60 \%$ of the overall Horizon 2020 budget should be related to sustainable development. ${ }^{1}$ Sustainable development is also a priority for European Member States, which are progressively adopting stricter market and non-market regulations for environmental policy.

Overall, innovation on the one hand and regulation on the other form the main pillars of the EU policy for sustainable development. However, we know very little on the single and joint impact of these policies on environmental innovation (EI). In particular, very few studies have investigated the relative effectiveness of different regulatory instruments (Johnstone and Labonne, 2006; Arimura et al., 2007; Lanoie et al., 2011) and, to the best of our knowledge, there exists no study which estimates the impact of participation in EU funded research networks for green innovation. Finally, the complementarity/ substitutability of the two policies has been largely neglected in the literature. This paper aims to shed light on these issues by bridging two lines of research on the determinants of environmental innovation: the numerous tests of the Porter hypothesis and the role of networks.

The Porter hypothesis, in its weak version, states that "properly designed environmental regulation may spur innovation" (Ambec et al., 2013, p.5). According to the narrow version "flexible regulatory policies give firms greater incentives to innovate and thus are better than prescriptive forms of regulation" (Ambec et al., 2013, p. 6). This suggests that market instruments (e.g. pollution taxes, deposit-fund schemes, tradable permits) are preferable to non-markets instruments (standards). Finally, the strong version of the hypothesis affirms that "in many cases this innovation more than offsets any additional regulatory costs-in other words, environmental regulation can lead to an increase in firm competitiveness" (Ambec et al., 2013, p.6).

Empirical studies, both at the firm and at the country level, have mainly found support for the weak and narrow versions of the Porter hypothesis while the evidence for the strong version is more controversial (see the surveys of Ambec et al., 2013, Rubashkina et al., 2015 and Morales Lage et al., 2016).

The literature on the role of networks for environmental innovation is more recent and less developed than that on regulation. It draws on the idea that environmental innovations require more heterogeneous sources of knowledge with respect to other innovations (Horbach et al., 2013). Empirical analyses have supported this view: environmentally innovative firms cooperate on innovation with external partners to a greater extent than other innovative firms (De Marchi, 2012; De Marchi and Grandinetti, 2013; Cainelli et al., 2015) and the breadth of the firm's knowledge sourcing has a positive effect on environmental innovation (Ghisetti et al., 2015). All these studies use firm level data

\footnotetext{
* Corresponding author.

E-mail address: vmeliciani@luiss.it (V. Meliciani).

${ }^{1}$ See http://ec.europa.eu/programmes/horizon2020/en/area/environment-climate-action.
} 
(mainly drawn from the Community Innovation Surveys) and, with the exception of Ghisetti et al. (2015) which use data from 11 European countries, focus on single countries (Italy or Spain).

Departing from previous studies, we use data from EU Framework Programmes to measure research cooperation among EU countries in fields related to sustainable development and we relate them to the capability to introduce environmental innovation (measured by green patents ${ }^{2}$ ). Moreover, following the policy mix literature (Flanagan et al., 2011; Guerzoni and Raiteri, 2015; Rogge and Reichardt, 2016; Costantini et al., 2017), we address the issue of whether research networks and regulations are complementary policy tools for EIs. We argue that this can be the case due to the presence in the environmental domain of multiple and self-enforcing market failures (Jaffe et al., 2005; Johnstone et al., 2010a, 2010b; Lehmann, 2012), including externalities, information failures and knowledge spillovers. This has relevant policy implications since the existence of complementarities would suggest that environmental policies, to be more effective, should not merely be regulation policies, but should be conceived also as industrial and innovation policies.

The paper makes use of two novel data sources. Green research networks are constructed using EU open data from the annual reports of Framework Programmes for Research and Technological Development of the EC Directorate for Research (FPs). This data allows us to compute the total number of participations in environmental networks at the country level and also to distinguish between universities, research centres and private companies. The source of data on environmental regulation is the OECD database on Environmental policy stringency (EPS) which provides composite indexes based on a selection of environmental policy instruments, primarily related to climate and air pollution. In our analysis, we choose two mid-level indexes obtained by grouping indicators into two broad categories of market-based and nonmarket instruments. This allows us to test both the weak and narrow versions of the Porter hypothesis. The analysis covers 23 European countries over the period 2003-2012.

The paper is organized as follows. Section 2 reviews the relevant literature and proposes some testable hypotheses. Section 3 presents the empirical strategy. Section 4 discusses data and provides descriptive statistics. Section 5 comments on the results of the empirical analysis. The last Section contains our concluding remarks.

\section{Background literature and research hypotheses}

In this section, we illustrate the main theoretical and empirical contributions to the literature on environmental innovation drivers and we develop the research hypotheses that will be tested in the econometric analysis on the determinants of new green knowledge. The main engines of EIs considered in this paper are represented by technologypush mechanisms, regulation and networking activities (see Fig. 1). ${ }^{3}$ These factors are discussed below.

\subsection{Technology push drivers}

EIs can be pushed by firms' R\&D, knowledge capital endowment (Horbach, 2008), organizational practices and management schemes (Ziegler and Rennings, 2004; Rennings et al., 2006; Wagner, 2007; Rehfeld et al., 2007; Ziegler and Nogareda, 2009). These factors can

\footnotetext{
${ }^{2}$ See Section 4 for definition of green patents and data source.

${ }^{3}$ Market drivers are also important and environmental policy actions are often designed to change consumer behaviours, perceptions and interact with firms' own strategies. Although this paper mainly focuses on regulation, knowledge networks and their interaction, we introduce some indicators of market conditions at macro level (such as GDP, exports) in the robustness checks, that can indirectly capture market drivers (Appendix C2 in the Supplementary material). Instead, for analyses directly focusing on market drivers at the micro level, see for instance Rehfeld et al. (2007), Horbach (2008), Kammerer (2009).
}

affect both standard and environmental innovations due to their potential complementarity.

Complementarity may arise from various channels. Firstly, environmental innovations generate the so called "dual externality" (or "double externalities") according to which on the one hand they reduce the negative externality concerning pollution, and on the other hand they generate knowledge spillovers involving both green and standard innovation processes (Jaffe et al., 2003; Rennings, 2000). Secondly, EIs can involve cumulative mechanisms of learning in which they can be the origin or the effect of standard innovations (Horbach, 2008; Guarini, 2015). Thirdly, economies of scope can be generated by the interaction between standard and green technologies (Johnstone et al., 2008). Consequently, the line between standard and environmental innovation processes can be thin.

Many empirical studies test the effectiveness of technological drivers. Some analyses focus on green and general R\&D and patents, with different measures of research activity such as R\&D as a percentage of GDP or number of researchers. According to Ghisetti and Pontoni (2015), the majority of empirical papers find a positive impact of R\&D (general and green) on environmental innovations, but the results are strictly dependent on the control variables considered and on the measurement of R\&D. In this paper, following most of the literature, we focus on general R\&D intensity as a technology push driver which is expected to positively affect environmental innovation.

\subsection{Regulatory drivers}

There is a growing literature studying and trying to estimate the impact of environmental regulation on green innovation (for recent reviews see Carraro et al., 2010; Popp et al., 2010; Ambec et al., 2013; Dechezlepretre and Sato, 2017). The rationale behind the induced innovation hypothesis, dating back to Hicks (1932), is that when regulations raise the cost of pollution relative to other production costs, firms have an incentive to develop new technologies reducing emissions. Porter and Van der Linde (1995) have further developed this idea, formulating the so-called "Porter Hypothesis" (PH). The theoretical incipit of the $\mathrm{PH}$ is that "the Panglossian belief that firms always make optimal choice [...]" is "true only in a static optimization framework" with "perfect information" and where "profitable opportunities for innovation have already been discovered" (Porter and Van der Linde, 1995, p.99), whereas real processes of competition and technological progress are characterised by "incomplete information", "organizational inertia" and "control problems". Therefore, innovations can be supported by public intervention, because through opportune instruments and means environmental regulation can arouse the Promethean spirit of entrepreneur, that otherwise might remain dormant. Regulation can promote innovation through five main channels: "First, regulation signals companies about likely resource inefficiencies and potential technological improvements." "Second, regulation focused on information gathering can achieve major benefits by raising corporate awareness." "Third, regulation reduces the uncertainty that investments to address the environment will be valuable". "Fourth, regulation creates pressure that motivates innovation and progress". "Fifth, regulation levels the transitional playing field. During the transition period to innovation-based solutions, regulation ensures that one company cannot opportunistically gain position by avoiding environmental investments." (Porter and Van der Linde, 1995, pp. 99-100).

Thus, not every regulation is innovative per se, but depends on the characteristics of the specific policy. According to Porter and Van der Linde (1995) the stringency of regulation is a crucial element. Indeed, lax regulation can be complied with by the firms through light solutions that do not significantly influence the production process, such as secondary treatments or "end-of pipe" interventions, while stringent regulation affects the entire production causing a reformulation of processes and products that can generate innovations. Hence, comparing the two types of regulation, the cost of compliance with lax 


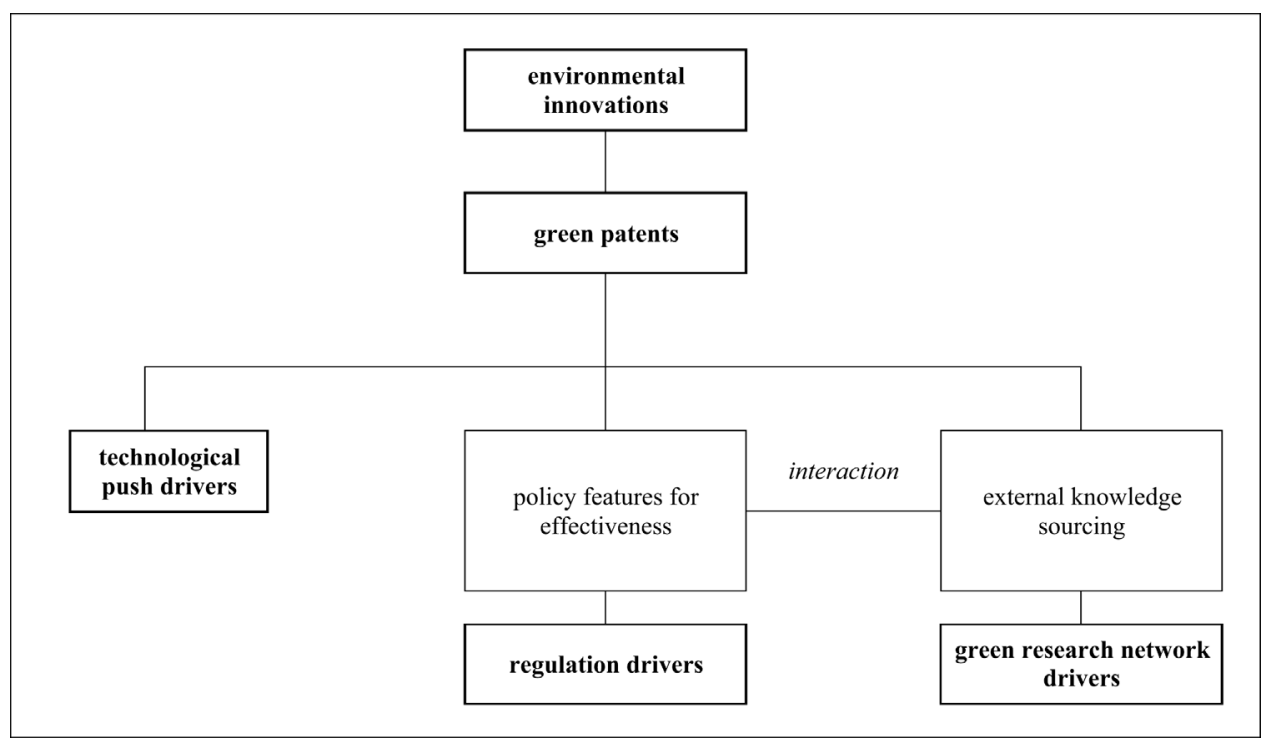

Fig. 1. The drivers of environmental innovations.

Source: authors.

regulation turns out to be more restrained, while the benefits of innovations springing from stringent regulation can be significantly more relevant. Johnstone et al. (2010b) have analysed the features that can positively affect the effectiveness of regulation policies: the stringency of regulation can produce the Hicksian incentive to innovate through minimising the new compliance costs; the predictability and stability of general norms and standards can reduce the uncertainty of investment projects; finally, other attributes influencing the implementation of regulation can be the incidence, flexibility and depth of regulatory instruments.

In order to synthetize the $\mathrm{PH}$, three versions of it have been formulated (Jaffe et al., 1995; Jaffe and Palmer, 1997; Ambec et al., 2013). The weak version says that "properly designed environmental regulation may spur innovation" (Ambec et al., 2013, p.5). The strong version affirms that "in many cases this innovation more than offsets any additional regulatory costs-in other words, environmental regulation can lead to an increase in firm competitiveness" (Ambec et al., 2013, p.6).

Finally, according to the narrow version that is the focus of our analysis "flexible regulatory policies give firms greater incentives to innovate and thus are better than prescriptive forms of regulation" (Ambec et al., 2013, p.6). Consequently, market instruments (e.g. pollution taxes, deposit-fund schemes, tradable permits) seem preferable to non-markets instruments as to mandating outcomes in providing greater incentives for invention, innovation and diffusion (Jaffe et al., 1995; Jaffe and Stavins, 1995). In fact, once a standard is satisfied there are no incentives to develop or adopt cleaner technologies, while in the presence of market based instruments the higher is emission reduction the higher are the benefits in terms of subsidies, revenues from tradeable permits or tax reductions. Moreover, in the case of standards, and particularly innovation standards, firms will be constrained in their choices with little incentives to develop new environmentally friendly technologies. Finally, firms may fear that environmental innovations will lead policy makers to raise previous standards.

Another related, although different, categorization is that between price-based instruments (which are always market based) and quantitybased instruments (which can be standards but also market based instruments such as tradable certificates/permits). In this respect, the literature has shown the superiority of price-based with respect to quantity-based instruments for dynamic efficiency (Menanteau et al., 2003; Schmidt et al., 2012; Costantini et al., 2015). Price-based instruments are perceived as more stable and predictable thus favouring long-term investment and innovation. Moreover, in the case of renewable energy sources, price-based instruments (feed in tariffs) increase producers' surplus creating a stimulus for eco-innovation while quantity based instruments only affect consumers' surplus (Menanteau et al., 2003). Overall the literature provides convincing theoretical arguments in favour of market-based instruments, and particularly pricebased ones, with respect to standards in stimulating environmental innovation.

Following the main recent surveys of Ambec et al. (2013), Rubashkina et al. (2015), Morales Lage et al. (2016) and Dechezlepretre and Sato (2017), we report the main results of the impact of environmental regulation on green innovation. Jaffe and Palmer (1997) and Brunnermeier and Cohen (2003) find, on a panel of manufacturing industries in US, that environmental compliance expenditures have a significant positive effect respectively on R\&D expenditures and on EI patents. These results are confirmed by studies using firm-level data. For example, Aghion et al. (2016) show that firms tend to innovate more in clean technologies when they face higher tax-inclusive fuel prices, while Calel and Dechezlepretre (2016) estimate that the European Union Emission Trading System (ETS) has increased low-carbon innovation among regulated firms by as much as $10 \%$, while not crowding out patenting for other technologies. Overall the literature supports the view that stricter regulations can induce innovation, ${ }^{4}$ although the overall impact on competitiveness indicators such as labour productivity, total factor productivity or exports is more ambiguous (Dechezlepretre and Sato, 2017).

Only a few contributions have empirically investigated directly or indirectly the narrow version of the $\mathrm{PH}$, that is the focus of our article. Burtraw (2000) for the USA in 1990 in connection with regulation of $\mathrm{SO}_{2}$ emissions, Hoglund Isaksson (2005) for Sweden during the period 1990-1996 in connection with abatement of $\mathrm{NO}_{\mathrm{x}}$ emissions, and Driesen (2005) in an empirical survey found that market-based instruments (such as pollution taxes, permits) are more effective than command and control instruments (such as emission caps, performancebased standards, technology-based standards). From the contribution of Labonne and Johnstone et al. (2008) it emerges that flexibility (more typical of market-based regulation) makes policies more successful, stimulating integrated investments strategies that generate economies of scope, rather than to fulfil normative requirements with "end-of pipe" solutions. Some studies (Johnstone and Labonne, 2006; Arimura

\footnotetext{
${ }^{4}$ See also Lanjouw and Mody, 1996; Popp, 2002, 2003, 2006; Arimura et al., 2007; Lanoie et al., 2011; Johnstone et al., 2010a.
} 
et al., 2007; Lanoie et al., 2011) use an OECD survey (including USA, Canada, France, Germany, Hungary, Japan, Norway) collected in 2003 on 4200 facilities in all manufacturing sectors, to test the narrow version of the $\mathrm{PH}$ with environmental R\&D as the dependent variable. Johnstone and Labonne (2006) find that market-based instruments positively affect EIs, while non-market-based instruments have a negative impact. Arimura et al. (2007) conclude that the effectiveness of regulatory policies does not depend on the type of instruments implemented. Popp (2003) and Taylor (2012) show that innovation decreased when traditional regulation was replaced by market instruments (permit trading). Finally, Lanoie et al. (2011) conclude that pollution taxes are not significant because they are not very widespread and stringent, while, among non-market-based instruments, performance-standards based instruments have a positive impact, and technology-based instruments are insignificant, because the former are more flexible than the latter.

In this paper, we test the narrow version of the PH. Previous studies, due to the scarcity of data on different policy instruments, have focused on a limited number of countries and on a few instruments. Therefore, there is room for an in-depth analysis covering many countries over a long-time period and using measures of stringency of regulatory policies with different instruments. In the light of the theoretical arguments discussed above, we test the following hypothesis:

Hypothesis 1. Market-based instruments are more effective in generating new green knowledge than non-market-based instruments

\subsection{Network drivers}

The final drivers of EI are research networks. Networks are crucial to the innovation process because they produce both static and dynamic economies of scale and they can foster knowledge spillovers. ${ }^{5}$

Moreover, networking appears to play a more important role for environmental innovations than for standard innovations (Horbach et al., 2013). With respect to the standard networks, environmental networks are more qualified, given the greater presence of high profile members outside the business world, such as universities and research organizations. This is due to the fact that the knowledge required for the implementation of clean technologies is more complex and more "codified" than that required for standard innovations (Cainelli et al., 2015). Environmental innovation processes require companies to implement significant changes in various directions that networking can appropriately support. These changes include the technical choices and the engineering aspects of the production (design dimension) (Braungart et al., 2007); the interaction with the market to satisfy consumers (users involvement); relationships with companies upstream and downstream of the production process in a supply chain perspective (product service dimension); relationships with local and national authorities (governance dimension) (Unruh, 2000). In summary, according to the literature, environmental networks are more heterogeneous, more selective for the specific skills required of participants, ${ }^{6}$ more effective, more focused on knowledge interactions and above all more crucial for the generation of profitable innovation dynamics.

Ghisetti et al. (2015) adapt to the EI context the open innovation mode formulated and tested by Chesbrough (2003) and Chesbrough et al. (2006). According to this mode, high and multiple competencies and codified knowledge spur firms to the external knowledge sourcing (EKS), whose pillars are the network breadth and depth. The network breadth helps the company to address two specific aspects of environmental innovations: their systemic nature and the multiple objectives

\footnotetext{
${ }^{5}$ For a review of the impact of networks on innovation, see Powell and Grodal (2006).

${ }^{6}$ See also Vona et al., 2015 for the relationship between environmental regulations and the demand for green skills and Consoli et al., 2016 for differences in terms of skill content and human capital between green and non-green job.
}

associated with them. For implementing or developing green innovations, multidisciplinary skills are required, including technical and scientific skills, legislative skills, managerial competencies (managing the complexity of the factors and parties involved) and economic competencies (turning environmental constraints into business opportunities). The greater the number of external parties with which a firm cooperates, the more likely it is to compensate for the lack of some specific internal competence. Moreover, the objectives to be pursued through the implementation of green technologies are multiple: these cover both the production efficiency and the quality of the product as required by the market and/or regulatory standards. In this context, external cooperation enhances the achievement of multiple objectives, eliminating any trade-off and taking advantage of possible economies of scope. Finally, EIs need multiple competencies and institutional agents such as universities and public research institutions.

The other important factor is the network depth. Cooperation among different actors inevitably involves a certain difficulty in communication and understanding. These problems can be mitigated by the solidity and stability of the established relationship. Strong networks can overcome the knowledge gap that is a potentially negative aspect of too large and heterogeneous networks. Moreover, lasting ties generate the process of learning-by-interacting. Thus, a knowledge partner becomes a crucial asset to maintain, possibly with the help of a strong and ongoing interaction. In evolutionary terms, the low availability of suitable knowledge sources means their selection and maintenance is crucial for the viability of learning-by-interacting.

Following the survey of Cainelli et al. (2015), we report the main results of the empirical evidence on the relevance of networks for EIs. Networking is fundamental for EIs mainly in manufacturing and its contribution varies across sectors. Cooperation with suppliers ensures supplies of materials are regular and collaboration of firms with services companies improves their relationship with customers; an intensive dialogue with all clients helps firms to make processes more resource efficient; finally, green networks are more numerous than standard networks. The literature also underlines the relevance of local networks and regional innovation systems that involve various levels of competition and knowledge to generate positive externalities for EIs.

To the best of our knowledge the literature on green networks has never focussed on environmentally related European Framework Programmes, one specific type of networks involving partners from different countries and different institutional sectors. However, this source of data has been used to estimate the impact of networks on general innovation (Maggioni et al., 2007; Hoekman et al., 2013; Di Cagno et al., 2014, 2016; Fabrizi et al., 2016). ${ }^{7}$ These studies have measured knowledge networks mainly at the regional or national level (using the number of joint memberships of regions/countries either in a bilateral matrix or as the row-total of the bilateral matrix, in some cases standardised by a total region/country participation or by population) and found them to positively affect patents and co-publications.

Departing from previous analyses, this paper focuses on environmentally related research networks emerging from EU Frameworks Programmes and involving international partners on green innovation. Hence, this new perspective investigates the relevance of foreign knowledge sourcing that can imply the integration of different institutional contexts, economic and social systems. In particular, we

\footnotetext{
${ }^{7}$ FP are just one special type of networks. In fact, the literature has identified several types of networks. For example Grabher and Powell (2004) focus on temporal stability and forms of governance to differentiate four, possibly overlapping, key types: informal networks (based on shared experience); project networks (short-term combinations to accomplish specific tasks); regional networks (where spatial propinquity helps sustain a common community); and business networks (purposive, strategic alliances between two parties). FP are European project networks involving universities, firms and research centers from several countries. Their organization, the type of cooperation or the overall performance of these programmes have been analysed in several studies (Luukkonen, 2000, 2002; Caloghirou et al., 2001; Arnold et al., 2005; Arranz and De Arroyabe, 2006 and 2007; Paier and Scherngell, 2011).
} 
test the following hypothesis:

Hypothesis 2. European green research networks stimulate the generation of new green knowledge

Following the literature, we can distinguish between two different modes of innovation: the Science, Technology and Innovation mode (STI mode) where universities and research centres play a central role and the Doing, Using and Interacting mode (DUI mode), i.e. an experienced learning typical of the business context (Jensen et al., 2007). Using this categorization for studying knowledge drivers of Spanish manufacturing firms' eco-innovations, Marzucchi and Montresor (2017) find that an "attenuated" STI mode prevails for firms' internal innovation, while among external knowledge sources synthetic knowledge matters more than analytical knowledge, suggesting instead a DUI mode. However, their dependent variable is firms' engagement in ecoinnovative strategies, while when patents are considered the STI mode could be more important than the DUI mode. In fact, in the case of ecological investments uncertainty and irreversibility are two very relevant factors (see for instance Dixit and Pindyck, 1994, Pindyck, 2007). Therefore, universities and governments can support firms in investing in environmental fields by offering economic incentives and by transferring complex knowledge. Very few empirical studies have tested this important feature of EIs. Triguero et al. (2013) find that across European countries in 2011 SMEs interacting with institutional agents are better performing in terms of eco-patents. De Marchi and Grandinetti (2013), using the Italian Community Innovation Survey (CIS) in 2008, show that, with respect to standard innovations, EIs are more sensitive to collaborations with universities and research centres. Thus, we put forward the following testable hypothesis:

Hypothesis 3. In green research networks the contribution of universities and public research centres to the generation of new green knowledge is positive and higher than the contribution of private firms

\subsection{Interaction between regulatory and networks drivers}

We have synthetically illustrated two relevant drivers of EIs: the regulatory driver, mainly summarized in the $\mathrm{PH}$, and networking. The literature has mostly analysed them separately as two distinct research fields. However, the combination of various policy instruments may be, under some circumstances, more effective in stimulating environmental innovation than the single policies. Lehmann (2012) suggests two rationales for using a policy mix for pollution control: helping to correct for multiple reinforcing market failures such as pollution externalities and technological spillovers and when the implementation of single policies brings about high transaction costs. Following the literature on policy mix, ${ }^{8}$ we argue that the combined effect of regulatory policies and research network policies can magnify the effects of the single policies. Complementarity may result from various sources.

First, network policies can help overcoming imperfect information problems, which can be particularly severe in the case of environmental innovation, thus increasing the innovation-enhancing potential of regulation policies. Firms with limited internal knowledge, and especially small firms (Brammer et al., 2012), may need the new knowledge and

\footnotetext{
${ }^{8}$ Cantner et al. (2016) find that the interaction between technology push and demand pull instruments for renewable energies in Germany is positive, suggesting complementarity between the two instruments. Costantini et al. (2017), in a dataset covering 23 OECD countries, find that when the policy mix is characterised by a more balanced use in demand-pull and technology-push instruments, its positive effects on eco-innovation tend to be greater. Mazzanti and Zoboli (2008), for a sample of manufacturing firms in Northern Italy, find evidence of complementarity with regard to R\&D and networking, but also cases where the main drivers of environmental innovation are not complementary. Although there are quite a number of studies looking at the effectiveness of policy mixes, we are not aware of any study investigating possible complementarities between regulation and network policies.
}

competencies deriving from cooperation with network partners in order to implement new products, processes and business models resulting in green innovation (Andersen, 2002; Millock et al., 2004; Mancinelli and Mazzanti, 2009; De Marchi and Grandinetti, 2013). Therefore, regulations can be more effective in stimulating innovation in the presence of networks helping firms to absorb and disseminate environmental knowledge.

Another possible source of complementarity between regulatory and network policies derives from overcoming coordination failures. Formal and informal networks may, in fact, allow better coordination of activities across different levels of government, between industries and regulators, among different countries and also between countries and international institutions. Indeed, Ostrom et al. (1999) and Ostrom (2005) define "adaptive governance" this manifold and flexible coordination and interplay across public and private agents, which is essential for eco-innovations due to their changeable, complex and multidimensional nature (Carrillo Hermosilla et al., 2009). In the specific case of FPs cooperation among firms, universities and research centres of different countries may favour knowledge spillovers avoiding the duplication of R\&D efforts which occurs when there is a different timing in the adoption of environmental regulation across countries (Popp, 2006) and, at the same time, lead to a more coordinated and, therefore, more effective environmental governance (Paavola, 2007).

Finally, the presence of a clear regulatory framework may provide incentives and guide the direction of research within networks. In fact, whenever innovation requires large investment in R\&D, the absence of reasonable stability or certainty in the regulatory framework can significantly hinder innovation (Ashford et al., 1985; Söderholm et al., 2007; Barradale, 2008; Johnstone et al., 2010a).

To our knowledge, there are no empirical contributions testing the complementarity between regulation and network policies, therefore we put forward the following original hypothesis:

Hypothesis 4. Regulatory policies and green research networks can be complementary tools for the generation of new green knowledge

\section{Empirical specification and econometric methodology}

\subsection{Empirical specification}

In order to test our hypotheses, we adopt the theoretical framework of the knowledge production function (KPF) as outlined initially in Griliches's work (1979). In spite of its highly simplifying assumptions, the KPF has been widely adopted and employed in the context of different streams of literature (innovation economics, new economic geography, the new endogenous growth theory) leading to positive results (Furman et al., 2002). Building on the contributions of Ghisetti et al. (2015), Ghisetti and Pontoni (2015), we construct a green KPF comprising three different drivers: technology, regulation and green networking as described above.

To summarise, in our green implementation of the KPF, new economically valuable green knowledge, proxied by green patents (Griliches, 1990; Nagaoka et al., 2010; Haöčič and Migotto, 2015) depends on the technology (general $R \& D$ expenditure as a percentage of GPD), on the networks (proxied by participation in FPs), and on the regulation drivers (proxied by the OECD Environmental Stringency Policy Indexes). We take account also of the interaction between the last two kinds of drivers. The following specifications are used to test Hypotheses 1-4:

$$
\begin{aligned}
G P_{i, t}= & \beta_{1} \ln R D_{i, t-s}+\beta_{2} \ln P O P_{i, t}+\beta_{3} \ln R E G_{i, t-s}+\eta_{i}+\mu_{t}+v_{i, t} \\
G P_{i, t}= & \beta_{1} \ln R D_{i, t-s}+\beta_{2} \ln P O P_{i, t}+\beta_{4} \ln S R E G_{i, t-s}+\beta_{5} \ln M R E G_{i, t-s}+\eta_{i} \\
& +\mu_{t}+v_{i, t}
\end{aligned}
$$




$$
\begin{aligned}
G P_{i, t}= & \beta_{1} \ln R D_{i, t-s}+\beta_{2} \ln P O P_{i, t}+\beta_{4} \ln S R E G_{i, t-s}+\beta_{5} \ln M R E G_{i, t-s} \\
& +\beta_{6} \ln N E T_{i, t-s}+\eta_{i}+\mu_{t}+v_{i, t} \\
G P_{i, t}= & \beta_{1} \ln R D_{i, t-s}+\beta_{2} \ln P O P_{i, t}+\beta_{4} \ln S R E G_{i, t-s}+\beta_{5} \ln M R E G_{i, t-s} \\
& +\beta_{7} \ln U N E T_{i, t-s}++\beta_{8} \ln G N E T_{i, t-s}+\beta_{9} \ln B N E T_{i, t-s}+\eta_{i}+\mu_{t} \\
& +v_{i, t} \\
G P_{i, t}= & \beta_{1} \ln R D_{i, t-s}+\beta_{2} \ln P O P_{i, t}+\beta_{6} \ln N E T_{i, t-s} \\
& +\beta_{10}\left(\ln S R E G_{i, t-s} \cdot \ln M R E G_{i, t-s}\right)+\eta_{i}+\mu_{t}+v_{i, t} \\
G P_{i, t}= & \beta_{1} \ln R D_{i, t-s}+\beta_{2} \ln P O P_{i, t}+\beta_{6} \ln N E T_{i, t-s} \\
& +\beta_{11}\left(\ln S R E G_{i, t-s} \cdot \ln N E T_{i, t-s}\right)+\eta_{i}+\mu_{t}+v_{i, t} \\
G P_{i, t}= & \beta_{1} \ln R D_{i, t-s}+\beta_{2} \ln P O P_{i, t}+\beta_{6} \ln N E T_{i, t-s} \\
& +\beta_{12}\left(\ln N E T_{i, t-s} \cdot \ln M R E G_{i, t-s}\right)+\eta_{i}+\mu_{t}+v_{i, t}
\end{aligned}
$$

In Eqs. (1)-(7) the dependent variable GP is green patents, ${ }^{9} i=1, \ldots$, $\mathrm{N}$ indexes countries (23 European countries), $t=2003, \ldots . ., 2012$ indexes time, whereas $\mathrm{RD}$ measures the expenditure on general $\mathrm{R} \& \mathrm{D}$ as a percentage of GDP; the variables SREG, MREG, REG are Environmental Stringency Policy Indexes, respectively non-market-based instruments, market-based instruments ${ }^{10}$ and the last is an average of these indices (regulatory drivers); regressors NET, UNET, GNET, BNET stand for the total number of members of green research networks promoted by the EU and, respectively, the total number of Universities, Government agencies, business firms belonging to these green research networks ${ }^{11}$; finally, the control variable POP is population, ${ }^{12} s$ stands for lag structure, $\eta$ are country fixed effects, $\mu$ is time effect and $v$ is a stochastic error. We estimate semi-logarithmic equations where all variables are expressed in logarithms, with the exception of green patents.

On the basis of previous studies on technology drivers, we expect $\beta_{1}>0$, i.e. a positive impact of research and development expenditure as a percentage of GDP on green patents. General R\&D also plays a policy role. Indeed, the European Union has promoted the Strategy "Europe 2020" for the period 2014-2020 to trigger economic processes geared to sustainable, inclusive and smart growth. The achievement of these pillars is monitored through specific target indicators. The variable RD is one of the main indicators to plan political initiatives for smart growth.

The first hypothesis (H1) on the differential impact of market-based versus non-market-based environmental policy instruments concerns condition $\beta_{4} \leq 0$ with $\beta_{5}>0$ or condition $\beta_{4}, \beta_{5}>0$ with $\beta_{5}>\beta_{4}$ and it is tested by using indicators derived from the Environmental Policy Stringency Indicators created by the OECD: namely SREG is the Environmental Policy Stringency Indicator for non-market-based instruments, MREG is Environmental Policy Stringency Indicator for market-based instruments, while REG is their arithmetic average. From the seminal article of Jaffe and Palmer (1997), most empirical studies that test the Porter Hypothesis use the pollution abatement and control expenditures (PACE) of firms as a consequence of environmental

\footnotetext{
${ }^{9}$ See next paragraph for the definition of green patents and the data source.

${ }^{10}$ Although we do not directly measure the price of oil, some of the components of the market-based EPS index are likely to be correlated with it. In fact, as illustrated in Botta and Koźluk (2014), the market-based EPS Index is a composite indicator where a relevant component is represented by environmental taxes, namely: CO2 tax, NOx Tax, SOx Tax (in the energy sector sub-indicator) and Tax on diesel for industry (in the economy-wide indicator): all these taxes lead directly or indirectly to an increase in the price of fuels which is expected to have similar effects on green patents as an increase in oil price. For a more detailed description of these indexes see Section 4.3.

${ }^{11}$ Participation in each country has been divided by the total number of participants across countries. In this way, the variable is more comparable in size to the regulation variables and we have more intuitive results for the interaction term between regulation and networks.

${ }^{12}$ See Appendix A (in the Supplementary material) for source, descriptive statistics and correlation of main variables.
}

regulation. But these indicators cannot measure the stringency of policy. The new OECD index is more in line with the PH approach. To our knowledge, it is the first time that the two sub-indices are used to test the narrow version of the PH. Prior to our article, Morales Lage et al. (2016) have used the final Environmental Policy Stringency Index to test the weak version, but since it also includes R\&D expenditure in renewable energies, it does not appear appropriate for the evaluation of regulation policies.

The second hypothesis (H2) involves the condition $\beta_{6}>0$; the green research networks (that will be described in the next section) are financed by the European Union and they are part of the European policy strategy to promote R\&D cooperation across countries to strengthen the competitiveness of the old continent in the global market. Thus, the variable "green research networks" assumes another important value: it represents an example of environmental policy.

The third hypothesis (H3) is verified if condition $\beta_{7}>0, \beta_{8}>0$ with $\beta_{7}, \beta_{8}>\beta_{9}$ holds.

Finally, the fourth hypothesis (H4) is verified if the term $s \beta_{10}, \beta_{11}$, $\beta_{12}$ have a positive effect on green patents. Since we consider the FP programmes as proxy of network driver, this hypothesis can be reinterpreted as a test of the complementarity between environmental policies. We also evaluate the magnitude of the interaction effects employing the method proposed by Ai and Norton (2003) to consider the use of a nonlinear model (see Appendix B in the Supplementary material). In fact, interaction effects in these models, that is the changes in the marginal effect of $x_{1}$ induced by changes in variable $x_{2}$, do not equal the marginal effect of the interaction term as in the linear model (Karaca Mandic et al., 2012). We also calculate the statistical significance of an estimate $[\mu(i e)]$ of these interaction effects (Table 6).

\subsection{Econometric methodology}

The estimated equations may be expressed in nonlinear count data panel model (or log-linear model) with the following conditional mean. In particular, for equation 3:

$$
\begin{aligned}
\mathrm{E}\left(P_{i, t} \mid x_{i, t-p}, \eta_{i}\right)= & \exp \left(\beta_{1} r d_{i, t-s}+\beta_{2} \text { pop }_{i, t}+\beta_{3} \text { sreg }_{i, t-s}+\beta_{4} \text { mreg }_{i, t-s}\right. \\
& \left.+\beta_{6} n e t_{i, t-s}+\eta_{\mathrm{i}}+\gamma_{\mathrm{t}}\right)
\end{aligned}
$$

where $r d=\ln (R D)$, pop $=\ln (P O P)$, sreg $=\ln (S R E G)$, mreg $=\ln (M R E G)$, net $=\ln (N E T)$

We use a version of the Negative Binomial model (NB2, or meandispersion model, Cameron and Trivedi, 2013) to estimate Eq. (8) that allows for correlated fixed effects. Its variance under the specification used here is:

$V\left(P_{i, t} \mid x_{i, t-s}, \eta_{i}\right)=\exp \left(x_{i, t-s}^{\prime} \beta+\eta_{i}\right)+\alpha\left[\exp \left(x_{i, t-s}^{\prime} \beta+\eta_{i}\right)\right]^{2}$

where the parameter $\alpha$ is a measure of "over-dispersion", relaxing the Poisson restriction that the mean equals the variance $(\alpha=0)$.

Following Blundell et al. $(1999,2002)$ we deal with unobserved heterogeneity by using the "pre-sample mean scaling" (PSM) method. This relaxes the strict exogeneity assumption underlying the approach of Hausman et al. (1984). The PSM method is just a moment based estimator of:

$E\left(P_{i, t} \mid x_{i, t-s}, \eta_{i}\right)=\exp \left(x_{i, t-s}^{\prime} \beta+\beta_{0}^{*}+\theta \ln \bar{P}_{i}\right)$

where $\overline{P_{i}}=(1 / T P) \sum_{T P-1}^{r=0} P A T_{i, 0-r}$ is the pre-sample mean of green patents where $T P$ is the number of pre-sample observations starting from 1977.

This model appears the most appropriate for our data for two main reasons. First, in our analysis it is likely that the unobserved components $\eta_{i}$ are correlated with the explanatory variables, $E\left[x_{i, t-s} \eta_{i, t}\right] \neq 0$, therefore, standard random effects estimators will be inconsistent. Second, in our study most of the variation is between variation rather than within variation (see Table A.2 in the Supplementary material), 
thus according to Cameron and Trivedi (2013) fixed effect estimators will not be very efficient because they rely on within variation. Finally, as stated by Bloom et al. (2013) pre-sample average "can then be used as an initial condition to proxy for unobserved heterogeneity under the assumption that the first moments of all the observables are stationary. Although there will be some finite sample bias, Monte Carlo evidence shows that this pre-sample mean scaling estimator performs well compared to alternative econometric estimators (like quasi-differenced Generalized Method of Moments estimator) for dynamic panel data models with weakly endogenous variables" (Bloom et al., 2013, p. 1367).

In order to reduce problems of endogeneity, and in particular the fact that regulations and participation in networks are partially a function of the green technological base of the country, we have lagged all regressors (except for population, that is a scale variable). Following Costantini et al. (2015) and Wang and Hagedoorn (2014) we have reported in the text results with one-year lag $(s=1)$.

The analysis includes 23 European countries over the period 2003-2012. The long-time series and large sample of countries makes the analysis different from other studies mainly focusing on a few countries and a short time period. Moreover, while other analyses are mainly at the firm level, our study is at national level. This allows estimating the impact of national regulation and international networks on national systems of innovation taking into account that environmental innovation is the result of the joint innovative effort of various agents, including firms, universities and research centres. Moreover, it also allows drawing conclusions and policy implications on the factors affecting the national innovation capacity (as defined in Furman et al., 2002) in the field of the environment. Finally, the recently released OECD database on Environmental Policy Stringency (EPS), providing composite indexes based on a selection of environmental policy instruments at the national level and over time, is particularly suitable for investigating the impact of market based and non-market based policies on national environmental innovations.

\section{Data and descriptive statistics for green patents, regulation, and network drivers}

\subsection{Green patents}

Data on green patents are extracted from the OECD PATSTAT database using search strategies for environment-related technologies (ENV-TECH) which were developed by the OECD staff specifically for this purpose (see Table 1 for a summary). This approach is based, for a large part, on the International Patent Classification (IPC) system, developed at the World Intellectual Property Organisation, that is a hierarchical system classifying inventions into more than 70,000 technological groups and subgroups. It allows identifying technologies

Table 1

Selected environment-related technologies.

Source: Haščič and Migotto (2015)

\begin{tabular}{ll}
\hline Environmental policy objective & Patent search strategy \\
\hline $\begin{array}{c}\text { a. Environmental health (human health } \\
\text { impacts) }\end{array}$ & $\begin{array}{l}\text { 1. Environmental management } \\
\text { technologies }\end{array}$ \\
b. Water scarcity & $\begin{array}{l}\text { 2. Water-related adaptation } \\
\text { technologies }\end{array}$ \\
c. Ecosystem health and biodiversity & 3. Biodiversity protection \\
& technologies \\
d. Climate change & 4. Climate change mitigation - Energy \\
& 5. Climate change mitigation - \\
& Greenhouse gases \\
& 6. Climate change mitigation - \\
& Transport \\
& 7. Climate change mitigation - \\
& Buildings \\
\hline
\end{tabular}

relevant to environmental management (as human and ecosystem health), water-related adaptation and climate change mitigation. An aggregate category labelled "selected environment-related technologies", that we use in the empirical section, includes all of these environmental domains (Haščič and Migotto, 2015).

Although patents have some drawbacks as indicators of technological activity (not all inventions are patented, the incentives to patent differ according to the sector and market, protection systems vary across countries, etc.) $)^{13}$ their use as a measure of output of the inventive process has become standard in the literature (Griliches, 1990; Hall et al., 1986) and there are very few examples of economically significant inventions which have not been patented (Dernis et al., 2001). For these reasons, we use green patents as a measure of environmental innovation.

In particular, we refer to green patent applications at the European Patent Office (EPO), based on country of residence of the inventor(s) and application date. We choose to focus on applications since they are closely tied to the timing of the new knowledge creation (Wang and Hagedoorn, 2014). In Fig. 2, we report the dynamics over the estimation period (2003-2012) for our sample of countries of three different green patent specifications: applications at the EPO, granted by the EPO and triadic, i.e. patents, by priority date, for which applications are filed to three different patent offices: European (EPO), United States (USPTO) and Japanese (JPO). We also add the total patent applications at the EPO (divided by ten per comparability) for comparison.

Green patents are expressed as fractional counts. This means that if inventors from two (three, or more) different countries are involved, only a fraction of 0.5 ( 0.33 , etc.) will be counted for a given patent application (Haščič and Migotto, 2015). Finally, the sum of fractional green patents for each country and year has been rounded to unit in order to have a "pure" count data. ${ }^{14}$

\subsection{FPs green programmes}

Data on joint research projects are drawn from the annual reports of Framework Programmes (FP) for Research and Technological Development of the EC Directorate for Research (FPs). FPs are multiannual and include both direct and indirect actions: direct actions are implemented by research institutes directly depending on the European Commission (such as the Joint Research Centre) and indirect actions are implemented by Member States, classified in the different sectors: business sector (or industry or non-public for profit), higher education and research sector (that we label government sector). This last category summarizes public for profit, public non-profit actors and other participants (see Fabrizi et al., 2016). FPs start in 1984. Now the Horizon programme 2020 is in course.

Regarding green programmes, as stated by European Commission (2008,2010) "The Framework Programmes have included environmental issues since the 1980s but the environmental research programme gained substantial momentum from the 1990s onwards" (European Commission, 2010).

Our green research networks are constructed using EU open data. ${ }^{15}$ Our data are related to projects that have green aspects. In particular, we use the following FPs/programmes/thematic priority (years): FP5EESD (1998-2002), FP6-SUSTDEV (2002-2006), FP7-ENERGY FP7-ENVIRONMENT FP7-TRANSPORT (2007-2012). In Table 2 we report their main characteristics.

We choose these programmes based on two characteristics: 1 ) they are strongly related to the environmental goal; 2) they stress the importance of technological development in attaining environmental

\footnotetext{
${ }^{13}$ For a discussion on the advantages and disadvantages of using patents as a measure of technological change see Archibugi and Pianta (1996).

${ }^{14}$ Results, available on request, are robust to using the fractional count as dependent variable.

15 https://data.europa.eu/euodp/data/.
} 


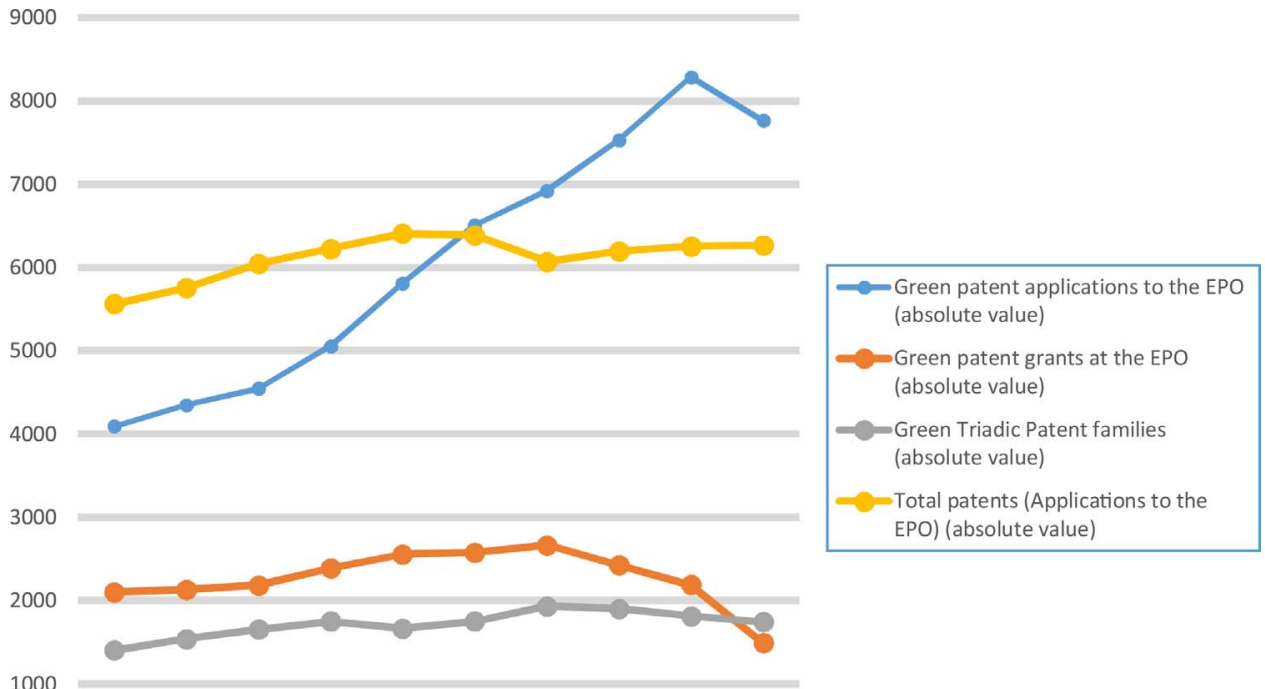

$\begin{array}{llllllllll}2003 & 2004 & 2005 & 2006 & 2007 & 2008 & 2009 & 2010 & 2011 & 2012\end{array}$

Fig. 2. Green patents dynamics.

Note: total patents applications to the EPO is divided by ten per comparability.

Source: our own elaborations on OECD data.

Table 2

The main characteristics of European green research programmes.

Source: our own elaborations on the EU OPEN FPs data.

\begin{tabular}{|c|c|c|c|c|c|c|c|c|}
\hline \multirow[b]{2}{*}{ FPs } & \multirow[b]{2}{*}{ Programme/Thematic Priority } & \multirow[b]{2}{*}{$\begin{array}{l}\text { Programme code/Thematic } \\
\text { area }\end{array}$} & \multirow[b]{2}{*}{$\begin{array}{l}\text { Budget } \\
\text { (millions) }\end{array}$} & \multirow[b]{2}{*}{ Projects } & \multirow[b]{2}{*}{ Participants } & \multicolumn{3}{|c|}{ By institutional sectors } \\
\hline & & & & & & $\begin{array}{l}\text { Business } \\
\text { enterprise }\end{array}$ & Government & $\begin{array}{l}\text { Higher } \\
\text { education }\end{array}$ \\
\hline 5 & $\begin{array}{l}\text { Energy, Environment and Sustainable } \\
\text { development }\end{array}$ & EESD & 2125 & 6513 & 10,398 & $34 \%$ & $37 \%$ & $29 \%$ \\
\hline 6 & $\begin{array}{l}\text { Sustainable Development, global change } \\
\text { and ecosystem }\end{array}$ & SUSTDEV & 2329 & 4819 & 9629 & $32 \%$ & $42 \%$ & $26 \%$ \\
\hline 7 & Cooperation & ENERGY & 1890 & 2199 & 2533 & $43 \%$ & $31 \%$ & $26 \%$ \\
\hline 7 & Cooperation & ENVIRONMENT & 2350 & 3656 & 4975 & $19 \%$ & $45 \%$ & $35 \%$ \\
\hline \multirow[t]{2}{*}{7} & Cooperation & TRANSPORT & 4160 & 4048 & 6316 & $51 \%$ & $27 \%$ & $22 \%$ \\
\hline & Total & & 12,854 & 21,235 & 33,851 & $35 \%$ & $37 \%$ & $28 \%$ \\
\hline
\end{tabular}

Note: Government sector summarizes public for profit, public non-profit actors and other participants.

goals. For instance, FP5-EESD states ${ }^{16}$ that the use of natural resources and ecosystems has to be inspired by a sustainable development perspective and that knowledge and technologies developed by the programme are instrumental in reconciling economic development with environmental sustainability. FP6-SUSTDEV also emphasizes ${ }^{17}$ the importance of strengthening science and technology as the main step for the EU to implement a sustainable development approach model in both the short and long term. It is noteworthy that adequate and timely solutions aimed to tackle the alarming trends in global energy demand and a coordinated approach at pan-European and international levels to face challenges posed by the increasing natural and man-made

\footnotetext{
16 "In a sustainable development perspective, we must address the quality and sustainability of our use of natural resources and ecosystems, threats of global change, quality of life in our cities, and the impact of the production and use of the energy which is essential to our economies and to our way of life, and also centrally important in environmental problems, notably climate change. Making use of the knowledge and technologies developed by this programme will make it possible to meet a wide range of social and economic needs so reconciling economic development with environmental sustainability." (source: CORDIS website: http://cordis.europa. eu/).

17 The main objectives "are strengthening the S\&T; capacities needed for Europe to be able to implement a sustainable development model in the short and in the long term, integrating its social, economic and environmental dimensions; contributing to international efforts mitigating adverse trends in global change". (source: CORDIS website: http://cordis.europa.eu/)
}

pressures are called for FP7-ENVIRONM ${ }^{18}$ and FP7-ENERGY ${ }^{19}$ respectively. Finally, FP7-TRANSPORT ${ }^{20}$ raises environmental awareness stating that transport is responsible for $25 \%$ of all the EU emissions of $\mathrm{CO} 2$

\subsection{The OECD EPS INDEX}

Environmental policy stringency (EPS) measures are extracted from the OECD database. These indexes have been developed by the OECD both for individual policy instruments as well as for overall environmental policy, and are defined "as a higher, explicit or implicit, cost of

\footnotetext{
18 "The challenges posed by the increasing natural and man-made pressures on the environment and its resources require a coordinated approach at pan-European and international levels." (source: CORDIS website: http://cordis.europa.eu/).

19 "The urgency to identify and develop adequate and timely solutions is justified by the alarming trends in global energy demand, the finite nature of conventional oil and natural gas reserves, and the need to dramatically curb greenhouse gas emissions. These actions would effectively mitigate the devastating consequences of climate change". (source: CORDIS website: http://cordis.europa.eu/).

20 Transport "is one of Europe's strengths - the air transport sector contributes to $2.6 \%$ of the EU GDP with 3.1 million jobs and the surface transport field generates 11\% of the EU GDP employing some 16 million persons. But, transport is also responsible for $25 \%$ of all the EU emissions of CO2." (source: CORDIS website: http://cordis.europa.eu/).
} 
polluting or environmentally harmful behavior" (Botta and Koźluk, 2014). The proposed definition is clearly relevant for instruments such as taxes or emission limit values, but harder to interpret for subsidizing instruments, such as feed-in tariffs. In this case, a higher subsidy can be interpreted as a more stringent environmental policy - such subsidies increase the opportunity costs of polluting and it can be assumed are paid by the bulk of tax payers or consumers, hence providing an advantage to "cleaner" activity.

The index proposed by the OECD seeks to compensate for the lack of reliable, comparable measures of the stringency of environmental policies which limited the possibility of cross-country analysis of the economic effects of these environmental policies (for a review, Koźluk and Zipperer, 2014).

The index is based on a selection of environmental policy instruments, primarily related to climate and air pollution, and scored and aggregated into composite indexes EPS for 29 countries $^{21}$ from 1990 to 2012. Two EPS indexes are proposed - one for the energy sector, and an extended one to proxy for the broader economy ("economy-wide"). The aggregation procedure, which is the same for both the energy and broader indicator, follows a two-steps approach. First, the instrumentspecific indicators (e.g. taxes on SOx, NOx and CO2) are aggregated into mid-level indicators according to their type (e.g. environmental taxes). Second, the obtained mid-level indicators are grouped into the two broad categories of market- based and non-market-based instruments. Subcomponents can be used and aggregated in various ways, for example to obtain "stick" and "carrot" versions of the indicators, where the former represents policies punishing environmentally harmful activity (e.g. taxes on pollutants), while the latter policies reward "environmentally-friendlier" activities (e.g. subsidies). At each level of aggregation, equal weights are applied, which reflects the lack of priors in this respect. In Table 3 we set out the list of variables grouped by categories.

In our analysis we choose two mid-level indexes obtained by grouping indicators into two broad categories of market-based and nonmarket instruments. For the non-market instruments, we do not use R\& $\mathrm{D}$ subsides because we already have the R\&D expenditure in relation to GDP as explanatory variable.

The two mid-level indexes do not allow capturing the differentiated and sometimes divergent effects of different policy instruments on ecoinnovation documented in the literature neither to shed light on the mechanisms linking different policy instruments to eco-innovation performance. However, they provide synthetic and comparable measures at the country level allowing to estimate the differentiated impact of market and non-market based instruments on eco-innovations.

Fig. 3 reports the evolution over time of two EPS sub-indexes: market and non-market (without renewable energy public R\&D budget). We can observe that both indexes exhibit an upward trend, however, after the financial crisis EPS have increased at a lower rate. Moreover, although some studies suggest that market-based instruments are more effective, non-market based ones have grown more over time.

\section{Main results and robustness checks}

\subsection{Main results}

The Negative Binomial regression model appears to fit well with data as shown by the results of the Wald test based on the parameter of over-dispersion Inalpha. Indeed, it is always significant, leading to the rejection of the null hypothesis of absence of dispersion. In all

\footnotetext{
${ }^{21}$ Australia, Austria, Belgium, Canada, Czech Republic, Denmark, Estonia, Finland, France, Germany, Greece, Hungary, Ireland, Italy, Japan, Korea, Luxembourg, Netherlands, New Zealand, Norway, Poland, Portugal, Slovak Republic, Spain, Sweden, Switzerland, Turkey, United Kingdom, United States.
}

Table 3

The OECD Environmental policy stringency (EPS) indicators. Source: Koźluk and Zipperer (2014)

\begin{tabular}{cl}
\hline Categories & Variables (economy-wide) \\
\hline $\begin{array}{c}\text { Market-based } \\
\text { policies }\end{array}$ & $\mathrm{Tax} \mathrm{CO}_{2}$, Tax Diesel, Tax $\mathrm{NO}_{\mathrm{x}}$, Tax $\mathrm{SO}_{\mathrm{x}}$, Trading Schemes \\
& $\mathrm{CO}_{2}$, Trading Schemes Green Certificates, Trading Schemes \\
& White Certificates, Feed-in Tariffs Solar, Feed-in Tariffs \\
& Wind, Deposit and Refund Schemes \\
Non-Market- & Emission limit values $\mathrm{NO}_{\mathrm{x}}$, Emission limit values PM, \\
based & Emission limit values $\mathrm{SO}_{\mathrm{x}}$, Sulphur content limit for diesel, \\
policies & Renewable energy public RD\&D budget \\
\hline
\end{tabular}

regressions, the pre-sample variable has a highly significant coefficient, confirming the presence of unobservable heterogeneity in the environmental knowledge production function. Consequently, the European national innovation systems appear heterogeneous probably due to permanent institutional, social and economic differences, in spite of the efforts of the European Union for more cohesion. Therefore, we will comment on the results based on the negative binomial method with pre-sample variables as summarised in Tables 4-6.

The positive and significant R\&D coefficient in all specifications shows the complementarity between standard and environmental innovations and technologies and is in line with the majority of empirical studies (see Ghisetti and Pontoni (2015) for a survey). Indeed, research activity concerns many fields and the environmental is not the main one; hence this result can be interpreted as the knowledge spillovers from the other lines of research. This result is important in setting up national research strategies that sustain and stimulate the interaction among researchers engaging in different research areas. Following this direction, European institutions reward the multidisciplinary of research projects. Essentially, the pervasiveness of environmental issues across social and economic dimensions is confirmed by the importance of general R\&D for EI.

The empirical results also give support to the narrow version of the Porter Hypothesis: the index summarising market-based instruments (MREG) has a positive and significant coefficient while the one regarding non-market-based instruments (SREG) is insignificant in most specifications. This result is in line with Johnstone and Labonne (2006) using data for a sample of OECD countries (Canada, France, Germany, Hungary, Japan, Norway and the United States) at the facility level. Thus, flexible and market-friendly policies can more effectively spur innovative processes, whereas the command and control policies do not drive innovation but rather can have a disincentive effect. For instance, by focussing only on the fulfilment of technological standards, firms may be induced not to search for new solutions along the technological frontier and this behaviour can lead to high opportunity costs. Finally, the average index (REG) is insignificant, pointing to the fact that the two main regulation policies are so different, in their nature and effects, that they should be separately evaluated (H1).

Green research networks appear to be important environmental innovation drivers, indeed the coefficient of the total number of participants in environment related European Framework Programmes is positive and significant. This result has several implications. Firstly, it confirms at the national level what empirical studies have found at the firm level about the relevance of external knowledge for environmental innovation (see Section 2). Secondly, since environmental issues need a large set of competencies and skills, innovative solutions can be found more easily through collaborations among agents belonging to different institutional sectors such as business, public administration and universities. Thirdly, environmental policies cannot be exclusively reduced to regulation, but they also require research network policies, that emphasize peculiar aspects of EIs. Fourthly, these results underline the effectiveness of European policies that promote collaboration across European member states (H2).

We have also tested the potential sectorial heterogeneity in the 


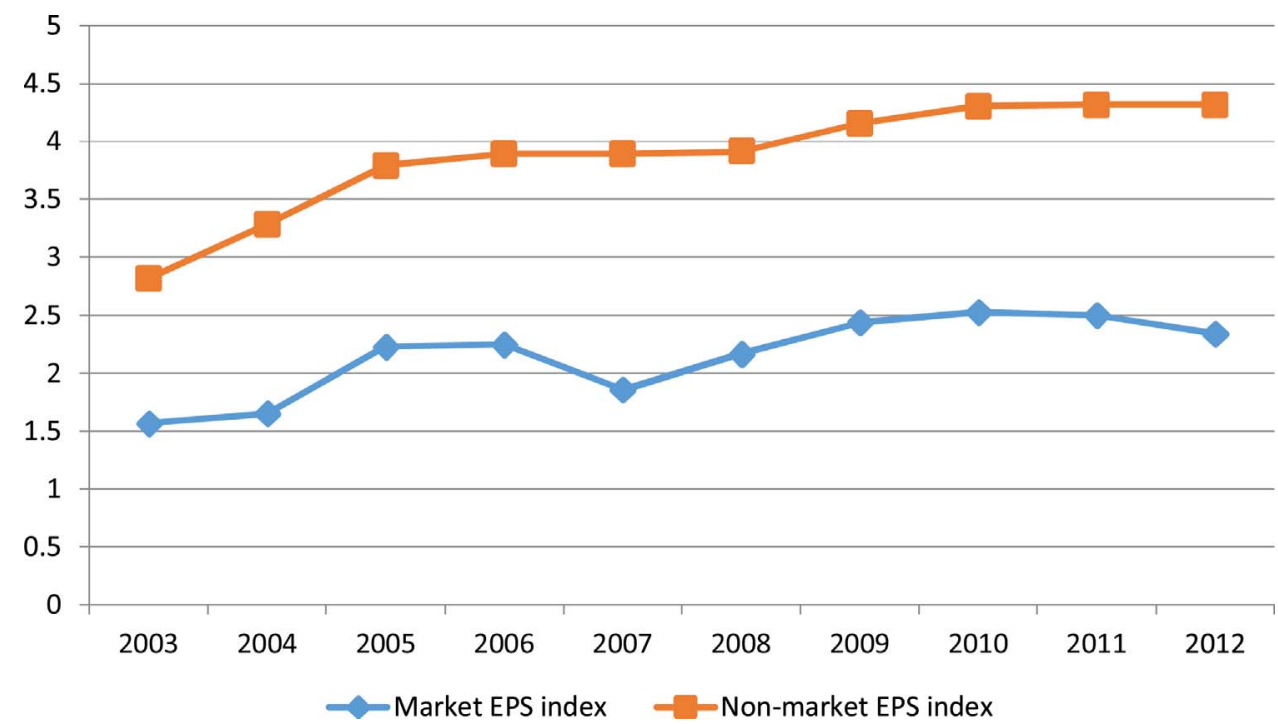

Fig. 3. The evolution of market and non-market EPS index.

Source: our own elaborations on OECD data.

Table 4

Regression results.

\begin{tabular}{|c|c|c|c|c|}
\hline & (1) & (2) & (3) & (4) \\
\hline \multicolumn{5}{|l|}{ Green patents } \\
\hline \multirow[t]{2}{*}{$\begin{array}{l}\ln \text { (Pre-sample fixed } \\
\quad \text { effect) }\end{array}$} & $0.603^{k * * * *}$ & $0.599^{* * * *}$ & $0.543^{\text {*k*k* }}$ & $0.462^{* * * k *}$ \\
\hline & (19.60) & (19.05) & (13.65) & (10.77) \\
\hline \multirow{2}{*}{$\ln (R \& D \text { intensity })_{t-1}$} & $0.584^{* * * *}$ & $0.605^{* * * k}$ & $0.666^{\text {*k*kt }}$ & $0.769^{\text {*⿻一𠃋火火k }}$ \\
\hline & $(5.39)$ & $(5.44)$ & $(6.07)$ & $(6.76)$ \\
\hline \multirow[t]{2}{*}{$\ln (\text { EPS index })_{t-1}$} & 0.131 & & & \\
\hline & (1.13) & & & \\
\hline $\ln (\text { Population })_{\mathrm{t}}$ & $\begin{array}{l}0.353^{k * k} \\
(8.98)\end{array}$ & $\begin{array}{l}0.360^{* * k} \\
(8.87)\end{array}$ & $\begin{array}{l}0.330^{\text {*k*ke }} \\
(8.36)\end{array}$ & $\begin{array}{l}0.370^{\text {***ke}} \\
(9.30)\end{array}$ \\
\hline $\ln (\text { EPS index STD })_{\mathrm{t}-1}$ & & $\begin{array}{l}-0.00658 \\
(-0.07)\end{array}$ & $\begin{array}{l}-0.0670 \\
(-0.72)\end{array}$ & $\begin{array}{l}0.105 \\
(1.16)\end{array}$ \\
\hline $\ln (\mathrm{EPS} \text { index MKT })_{\mathrm{t}-1}$ & & $\begin{array}{l}0.0865^{*} \\
(1.80)\end{array}$ & $\begin{array}{l}0.0840^{*} \\
(1.80)\end{array}$ & $\begin{array}{l}0.109^{* *} \\
(2.44)\end{array}$ \\
\hline $\begin{array}{l}\ln \text { (FPs participants } \\
\text { intensity })_{\mathrm{t}-1}\end{array}$ & & & $\begin{array}{l}0.140^{\text {*k }} \\
(2.15)\end{array}$ & \\
\hline \multirow[t]{2}{*}{$\begin{array}{l}\ln \text { (FPs HES participants } \\
\text { intensity })_{\mathrm{t}-1}\end{array}$} & & & & $0.0976^{*}$ \\
\hline & & & & $(1.90)$ \\
\hline \multirow[t]{2}{*}{$\begin{array}{l}\ln (\text { FPs GOV participants } \\
\text { intensity })_{\mathrm{t}-1}\end{array}$} & & & & $0.0986^{* * *}$ \\
\hline & & & & $(2.16)$ \\
\hline $\begin{array}{l}\ln \text { (FPs BES participants } \\
\text { intensity })_{\mathrm{t}-1}\end{array}$ & & & & 0.0783 \\
\hline Constant & $\begin{array}{l}-0.500 \\
(-0.88)\end{array}$ & $\begin{array}{l}-0.415 \\
(-0.75)\end{array}$ & $\begin{array}{l}1.082 \\
(1.37)\end{array}$ & $\begin{array}{l}(1.56) \\
1.580^{*} \\
(1.75)\end{array}$ \\
\hline \multicolumn{5}{|l|}{$\ln ($ alpha) } \\
\hline Constant & $\begin{array}{l}-2.147^{* * * *} \\
(-12.25)\end{array}$ & $\begin{array}{l}-2.156^{\text {***** }} \\
(-12.51)\end{array}$ & $\begin{array}{l}-2.263^{* * * *} \\
(-12.43)\end{array}$ & $\begin{array}{l}-2.426^{* * * *} \\
(-14.05)\end{array}$ \\
\hline Observations & 227.000 & 227.000 & 226.000 & 213.000 \\
\hline Log pseudolikelihood & -1079.557 & -1078.99 & -1067.414 & -1009.542 \\
\hline Wald chi2 & 4166.09 & 4193.725 & 4624.901 & 6004.926 \\
\hline Pseudo-R-squared & 0.2434002 & 0.2437982 & 0.2491386 & 0.2574637 \\
\hline
\end{tabular}

Note: $t$ statistics in parentheses. Estimations are conducted using the Negative Binomial model. Standard errors are robust to arbitrary heteroskedasticity. A full set of time dummies are included in all columns. Ln(alpha) is the estimate of the dispersion parameter.

Significance: ${ }^{*} p<0.1,{ }^{* * *} p<0.05,{ }^{* * * * *} p<0.01$.

impact of participation in FP on the environmental knowledge production function. From the empirical estimates, it emerges that universities and public research centres have a crucial role in the creation
Table 5

Regression results with interaction terms.

\begin{tabular}{|c|c|c|c|}
\hline & (5) & (6) & (7) \\
\hline \multicolumn{4}{|l|}{ Green patents } \\
\hline $\ln$ (Pre-sample fixed effect) & $\begin{array}{l}0.532^{* * * k} \\
(14.08)\end{array}$ & $\begin{array}{l}0.496^{k * k} \\
(11.47)\end{array}$ & $\begin{array}{l}0.517^{* / 2 * k} \\
(13.34)\end{array}$ \\
\hline $\ln (\mathrm{R} \& \mathrm{D} \text { intensity })_{\mathrm{t}-1}$ & $\begin{array}{l}0.644^{\text {*x*x }} \\
(5.94)\end{array}$ & $\begin{array}{l}0.731^{* * *} \\
(6.33)\end{array}$ & $\begin{array}{l}0.682^{* x / k} \\
(6.16)\end{array}$ \\
\hline $\ln (\text { FPs participants intensity })_{\mathrm{t}-1}$ & $\begin{array}{l}0.189^{k * k x} \\
(3.22)\end{array}$ & $\begin{array}{l}0.0587 \\
(0.75)\end{array}$ & $\begin{array}{l}0.160^{* * * k} \\
(2.76)\end{array}$ \\
\hline $\ln (\text { Population })_{t}$ & $\begin{array}{l}0.303^{k * k} \\
(7.63)\end{array}$ & $\begin{array}{l}0.322^{* * * k} \\
(8.00)\end{array}$ & $\begin{array}{l}0.303^{* x / k} \\
(7.25)\end{array}$ \\
\hline $\ln (E P S \text { index STD })_{t-1}$ & $\begin{array}{l}-0.101 \\
(-1.01)\end{array}$ & $\begin{array}{l}0.472^{*} \\
(1.89)\end{array}$ & $\begin{array}{l}-0.0482 \\
(-0.52)\end{array}$ \\
\hline $\ln (\mathrm{EPS} \text { index MKT })_{\mathrm{t}-1}$ & $\begin{array}{l}-0.289^{*} \\
(-1.83)\end{array}$ & $\begin{array}{l}0.0916^{* *} \\
(2.01)\end{array}$ & $\begin{array}{l}0.510^{* * * k} \\
(3.26)\end{array}$ \\
\hline $\begin{array}{l}\ln (\text { EPS index STD })_{\mathrm{t}-1} \times \ln (\text { EPS index } \\
\quad \text { MKT })_{\mathrm{t}-1}\end{array}$ & $\begin{array}{l}0.307^{\text {*x }} \\
(2.54)\end{array}$ & & \\
\hline $\begin{array}{c}\ln (\text { EPS index STD })_{\mathrm{t}-1} \times \ln (\mathrm{FPs} \\
\text { participants intensity })_{\mathrm{t}-1}\end{array}$ & & $\begin{array}{l}0.140^{* *} \\
(2.17)\end{array}$ & \\
\hline $\begin{array}{c}\ln (\text { EPS index MKT })_{\mathrm{t}-1} \times \ln (\mathrm{FPs} \\
\text { participants intensity })_{\mathrm{t}-1}\end{array}$ & & & $\begin{array}{l}0.115^{* x / k} \\
(2.66)\end{array}$ \\
\hline Constant & $\begin{array}{l}1.620^{\text {** }} \\
(1.99)\end{array}$ & $\begin{array}{l}1.231 \\
(1.49)\end{array}$ & $\begin{array}{l}1.688^{* * \hbar} \\
(1.97)\end{array}$ \\
\hline \multicolumn{4}{|l|}{$\ln ($ alpha) } \\
\hline Constant & 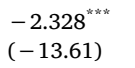 & $\begin{array}{l}-2.281^{\text {**kk}} \\
(-13.17)\end{array}$ & $\begin{array}{l}-2.288^{* * * k} \\
(-13.11)\end{array}$ \\
\hline Observations & 226.000 & 226.000 & 226.000 \\
\hline Log pseudolikelihood & -1061.513 & -1062.355 & -1060.562 \\
\hline Wald chi2 & 5397.744 & 5414.939 & 5441.313 \\
\hline Pseudo-R-squared & 0.2532895 & 0.2526974 & 0.2539584 \\
\hline
\end{tabular}

Note: $t$ statistics in parentheses. Estimations are conducted using the Negative Binomial model. Standard errors are robust to arbitrary heteroskedasticity. A full set of time dummies are included in all columns. Ln(alpha) is the estimate of the dispersion parameter.

Significance: ${ }^{*} p<0.1,{ }^{* * *} p<0.05,{ }^{* * * *} p<0.01$.

of new knowledge; indeed, the coefficient of the academic sector and of the public administration are positive and significant, whereas the business sector has an insignificant coefficient.

This result is particularly interesting also considering that patent data should better capture innovative activities pursued by firms with respect to those implemented by other actors. A possible interpretation is that cooperation in R\&D networks make universities and public 
Table 6

Interaction effects.

\begin{tabular}{|c|c|c|c|c|c|c|c|}
\hline Equation & Formula & Coef. & Std. Err. & $\mathrm{z}$ & $\mathrm{P}>|\mathrm{z}|$ & $95 \%$ Conf. Interval & \\
\hline (5) & $\partial^{2} \mathrm{GP} \mid \partial($ SREG MREG) & 20.423 & 8.076 & 2.53 & 0.011 & 4.593 & 36.252 \\
\hline (6) & $\partial^{2} \mathrm{GP} \mid \partial($ SREG NET) & 0.460 & 0.233 & 1.97 & 0.049 & 0.003 & 0.916 \\
\hline (7) & $\partial^{2} \mathrm{GP} \mid \partial(\mathrm{MREG}$ NET) & 1.100 & 0.364 & 3.02 & 0.003 & 0.386 & 1.814 \\
\hline
\end{tabular}

Note: see Appendix B (in the Supplementary material) for a detailed presentation of interaction effects' computation.

research centres more concerned about the appropriability and possible commercialization of inventions. ${ }^{22}$ This may be good for allowing new knowledge to be exploited in industry but also raises the concern that intellectual property rights on academic research, by reducing its accessibility, may discourage the cumulative process of advancing knowledge by building upon other scientists' ideas (Foray and Lissoni, 2010). In the case of green patents, the larger role played by universities appears coherent with the idea, developed and tested in the literature, that the environmental innovation processes mainly require codified and complex knowledge typical of the Science, Technology and Innovation mode (STI mode). Another interesting point that can be emphasized is that environmental innovations are complex not only from the technological point of view. With respect to standard investments, investments in sustainability have more uncertain and more long term returns and this can curtail firms from investing in green projects. On the other hand, universities, but also governments, thanks to their publicly funded activities and institutional mission are more sensitive to ecological challenges, and thus more inclined to long term investments (H3).

Table 5 reports the results of the estimations that take into account three types of interactions: between regulatory variables and between networks and respectively non-market-based instruments and marketbased instruments. ${ }^{23}$ In addition, Table 6 reports the estimates of the total impact for every variable (see Appendix B in the Supplementary material). All the above-mentioned interactions are significant and positive giving support to the following theoretical and policy arguments. ${ }^{24}$ Coordination across regulatory policies is necessary and effective in incentivising EIs: this idea, that was highlighted by Porter and Van der Linde (1995), has been under-investigated in the literature and should be taken into due consideration. Future analyses should study the mechanisms of interaction that are complex because they involve the collaboration of different public institutions.

The positive and significant interaction between regulation and green research networks confirms the relevance of the sources of their complementarity. First, firms involved in research networks, by having access to external knowledge, are more likely to effectively exploit the innovation enhancing potential of environmental regulations. Secondly, cooperation in European research networks can help overcoming coordination failures leading to a more effective environmental governance. Moreover, environmental regulations may increase the effectiveness of research networks by providing the right incentives and a stable framework which facilitate green innovations. ${ }^{25}$

\footnotetext{
${ }^{22}$ A similar result is found for all patents (rather than only green patents) by Fabrizi et al. (2016).

${ }^{23}$ We have also tried interactions between regulatory policies and participants in green networks distinguished in the institutional sectors of business, public administration and universities. These interactions were not significant indicating that synergies between regulatory and network policies require composite networks formed by agents belonging to different insttutional sectors.

${ }^{24}$ Note that in Table 5, column 5 the coefficient on market regulation becomes negative. However, the overall effect of all regulatory variables taking into account their interaction is positive and significant as shown in Table 6 .

25 Indeed, the stringency of regulation can be interpreted also as a proxy of the institutional and social sensitivity to ecological problems, thus it can be a sort of "institutional absorptive capacity" of green external knowledge. It could represent the "environmental case" of the so called "Quality of institutions and governance system" (Castellacci and Natera, 2013; Varsakelis, 2006; Fagerberg and Srholec, 2008): the more
}

In conclusion, the abovementioned positive interactions reflect the multiform nature of environmental policies that should entail variegated strategies in order to activate the multiple sectors and factors involved in the complex processes generating EIs. Therefore, in order to be more effective, environmental policies should exploit the synergies between regulatory policies and research network policies (H4).

\subsection{Robustness checks}

In order to test for the robustness of our results, we have performed a series of checks addressing econometric concerns, using alternative measures of patents and networks and excluding the possible presence of outliers.

A first econometric issue can be the endogeneity of some regressors. Although in the estimations we use one-year lags of the explanatory variables, this might not be sufficient to exclude problems of endogeneity due to the likely persistence of the series. Therefore, in Appendix C (in the Supplementary material) we report robustness checks with longer lags and using a Generalized Method of Moments (GMM) estimator for count data allowing regulation and participation in networks to be endogenous to green patents. Moreover, similarly to Bloom et al. (2013), we implement a two steps procedure which includes the residual of the first stage regressions of endogenous variables (market regulation and participation in networks) as regressors of our model in the second stage.

Another limit of our estimates can be the presence of omitted variables that are likely to be correlated with green patents and with our explanatory variables resulting in biased coefficients. Although the pre-sample mean should alleviate this problem (Blundell et al., 2002), we report in Appendix C (in the Supplementary material) also robustness checks including among regressors per-capita GDP and the stock of green patents. $^{26}$

A further concern relates to using patent applications as a measure of green innovations since many patents have poor technological and economic relevance. To reduce this problem, and in order to be more confident that we are dealing with relevant patents, we perform robustness tests with triadic patents, i.e. patents for which applications are filed to three different patent offices: European (EPO), United States (USPTO) and Japanese (JPO). ${ }^{27}$ Moreover, following Squicciarini et al. (2013) and Costantini et al. (2017), we also use citation weighted patents, i.e. patents weighted by forward citations in the five years after their publication. ${ }^{28}$

\section{(footnote continued)}

institutional attention devoted to sustainability, the greater the institutional efforts to sustain the technological adaptions of production systems towards environmental innovations.

${ }^{26}$ We have also included the one-year lagged growth in GDP (as a proxy for a growth in demand) and the share of exports on GDP but they were not significant. Results are available on request.

27 The number of patent offices at which a given invention has been protected is considered a proxy of its economic value and an indicator of the quality of the related patent (Squicciarini et al., 2013).

28 To derive the citation weighted green patents, we use the "OECD, REGPAT database, February 2016" to select the environment-related technologies. To simplify our search strategy, considering that we use this indicator only for robustness checks, we refer to the "Y02" tagging scheme focussing on the climate change mitigation technologies in the energy, transport and building sectors (Haščič and Migotto, 2015). We then match this 
Final robustness checks include estimating the model without Germany (due to the high concern in this country for environmental innovation we want to rule out the possibility that Germany drives our results) and standardizing the total number of members of green research networks by population. All robustness checks are performed on the specifications including the interaction between regulation and networks $^{29}$ (equations 6 and 7, see Tables C1 and C2 respectively).

Results are broadly consistent with those found in the basic specification. Market-based instruments have a positive and significant impact on green patents in most specifications and positively interact with participation in networks, supporting the complementarity hypothesis. On the other hand, the impact of non-market-based instruments is weaker and the coefficient is not significantly different from zero in several specifications, supporting the hypothesis that command and control policies are less effective in generating new green knowledge with respect to market-based instruments. ${ }^{30}$ Finally, when significant, the impact of non-market based instruments is amplified by the presence of networks.

\section{Concluding remarks}

This paper has investigated the determinants of environmental innovation for a sample of European countries. We have found that among regulatory variables, market-based instruments are more effective than non-market based ones in stimulating EI, giving support to the narrow version of the Porter hypothesis. We have also made use of information on participation in EU Framework Programs related to energy and environment in order to test whether research networks can be complementary instruments to regulatory policies. The results of the econometric analysis have shown a positive and robust effect of such networks with collaborations with universities and public research centres producing the largest positive effects.

While previous analyses found some support for the important role played by external sources of knowledge for EI at the firm level, we hope to have enhanced the literature by showing the relevance of the network effect also at the country level for a large sample of European countries observed over time. The prominent role played by universities and public research centres with respect to private companies in environmental networks supports the view that the knowledge required for the implementation of clean technologies is more complex and more "codified" than that required for other types of innovation (Cainelli et al., 2012). This result also suggests that the current concern on increasing firms' participation in FPs may be partly misleading, at least in the case of green research networks. In fact, the high level of complexity of environmental innovations makes the presence of high scientific profile members outside the business world, such as universities and research organizations, essential for innovation. Moreover, networks involving universities and public research centres lead to inventions that are patented and possibly commercialized, giving support to the existence of complementarities between scientific performance and the creation of commercial value (Rothaermel et al., 2007). Finally, the fact that private actors appear to contribute less than public ones to green patents generation raises the question of the importance for firms of

\footnotetext{
(footnote continued)

sample with the "OECD Patent Quality Indicators database, September 2017" and we build a count indicator based on forward citations in the five years after publication, normalized (range $0-1$ ) per year. The number of forward citations a given patent receives reflects, to a certain extent, the economic value of inventions. The 5 years citation lag decreases the timeliness of the indicator: only patents published up to the year 2009 can thus be considered (Squicciarini et al., 2013). For this reason, the regressions in tables C1 and C2 refer to the years 2003-2009. Data are fully available on request.

${ }^{29}$ Robustness checks for other specifications are available on request.

${ }^{30}$ Namely, non-market-based instruments are insignificant in the regression where the dependent variable is represented by high values patents: triadic patents and citation weighted green patents. This interesting empirical evidence can be the starting point for further research.
}

investing in human capital in order to increase the level of absorptive capacity that allows recognising, assimilating and implementing external knowledge by governing the exchange of knowledge flows among co-operating agents (Vega Jurado et al., 2008)".

Another novel aspect of this paper has been to test the joint effect of regulation and network drivers for EI. The empirical analysis has shown the presence of complementary effects, suggesting that in order to be more effective, environmental policies should simultaneously use regulatory instruments (preferably marked-based ones) and policies stimulating collaborative research (preferably involving the participation of universities and research centres).

Overall, it is important to point out that the logic of regulatory and innovation policies is very different. In principle neither type of policy should be necessary to stimulate environmental innovations as long as they have "win-win" effects whereby firms combine competitiveness and environmental sustainability (Porter and Van der Linde, 1995). However, market-failures, including imperfect information and environmental externalities, justify the existence of environmental regulations.

A similar logic can explain the use of innovation policies to stimulate the creation of research networks, which internalize new knowledge creation and can create positive externalities allowing countries to develop along a sustainable path. However, as opposed to regulations, the financing of cooperative research is costly and, therefore, it is important to evaluate its effectiveness and its complementarity to environmental regulations. The results of this paper are encouraging in this respect.

Results on complementarity have important policy implications since they suggest that the joint use of regulatory policies and innovation policies may enhance the impact of each of the two single policies on environmental innovations. Exploiting such complementarities requires not only the coordination between different policy institutions, but also between institutions and the research community. In particular, when setting environmental regulations, policy makers should be aware of the directions of environmental research and innovation emerging from national and international research networks. This requires cooperation between networks (involving firms, universities and research centres) and the regulatory bodies, either through joint participation in research projects or through the strengthening of the mechanisms facilitating the diffusion of the results of research projects to policy makers. This is particularly important in the case of FPs considering their size, level of funding and international character. Moreover, finding mechanisms favouring the involvement of firms, and particularly SMEs, in green FPs may help overcoming information asymmetries, leading companies to adopt environmental solutions with better long-term prospects and ensuring higher levels of environmental sustainability in the long run.

Our contribution has investigated the impact of participation in green networks on EI only computing the number of participations and the nature of participating institutions. Future research could also investigate whether the heterogeneity of nationalities, the types of countries involved also in terms of proximity effects both in the geographical and knowledge spaces and the overall scientific competencies of participants in such networks matter. Moreover, the analysis can be extended to test the stronger version of the Porter hypothesis by simultaneously estimating the impact of regulation and networks on EI and on international competitiveness.

\section{Appendix A. Supplementary data}

Supplementary data associated with this article can be found, in the online version, at https://doi.org/10.1016/j.respol.2018.03.005.

\section{References}

Aghion, P., Dechezlepretre, A., Hemous, D., Martin, R., Van Reenen, J., 2016. Carbon 
taxes, path dependency and directed technical change: evidence from the auto industry. J. Polit. Econ. 124 (1), 1-51.

Ai, C.R., Norton, E.C., 2003. Interaction terms in logit and probit models. Econ. Lett. 80 (1), 123-129.

Ambec, S., Cohen, M., Elgie, S., Lanoie, P., 2013. The porter hypothesis at 20: can environmental regulation enhance innovation and competitiveness? Rev. Environ. Econ. Policy 7 (1), 2-22.

Andersen, M.M., 2002. Organising interfirm learning: as the market begins to turn green. In: de Bruijn, T.J.N.M., Tukker, A. (Eds.), Partnership and Leadership: Building Alliances for a Sustainable Future. Kluwer, Dordrecht, pp. 103-119.

Archibugi, D., Pianta, M., 1996. Measuring technological change through patents and innovation surveys. Technovation 16 (9), 451-468.

Arimura, T., Hibiki, A., Johnstone, N., 2007. An empirical study of environmental R\&D: what encourages facilities to be environmentally-Innovative? In: Johnstone, N. (Ed.), Corporate Behaviour and Environmental Policy. Edward Elgar, Cheltenham, pp. 142-173.

Arnold, E., Clark, J., Muscio, A., 2005. What the evaluation record tells us about European Union Framework Programme performance. Sci. Publ. Policy 32 (5), 385-397.

Arranz, N., De Arroyabe, J.C.F., 2006. Joint R\&D projects: experiences in the context of European technology policy. Technol. Forecast. Soc. 73 (7), 860-885.

Ashford, N., Ayers, C., Stone, R.F., 1985. Using regulation to change the market for in novation. Harvard Environ. Law 9 (2), 419-466.

Barradale, M.J., 2008. Impact of Policy Uncertainty on Renewable Energy Investment: Wind Power and PTC, US Association for Energy Economics. Working Paper 08-003, mimeo.

Bloom, N., Schankerman, M., Van Reenen, J., 2013. Identifying technology spillovers and product market rivalry. Econometrica 81, 1347-1393.

Blundell, R., Griffith, R., Van Reenen, J., 1999. Dynamic count data models of technological innovation. Econ. J. 105 (429), 333-343.

Blundell, R., Griffith, R., Windmeijer, F., 2002. Individual effects and dynamics in count data. J. Econom. 108, 113-131.

Botta, E., Koźluk, T., 2014. Measuring Environmental Policy Stringency in OECD Countries: A Composite Index Approach. OECD Economics Department Working Papers 1177. OECD Publishing.

Brammer, S., Hoejmose, S., Marchant, K., 2012. Environmental management in SMEs in the UK: practices, pressures and perceived benefits. Bus. Strateg. Environ. 21 (7), 423-434.

Braungart, M., McDonough, W., Bollinger, A., 2007. A cradle-to-cradle design, creat-ing healthy emissions: a strategy for eco-effective product and system design. J. Clean. Prod. 15 (13-14), 1337-1348.

Brunnermeier, S.B., Cohen, M.A., 2003. Determinants of environmental innovation in US manufacturing industries. J. Environ. Econ. Manag. 45 (2), 278-293.

Burtraw, D., 2000. Innovation Under the Tradeable Sulphur Dioxide Emission Permits Programme in the US Electricity Sector. Discussion Paper 00-38. Washington, D.C.: Resources for the Future.

Cainelli, G., Mazzanti, M., Montresor, S., 2012. Environmental innovations. Local networks and internationalization. Ind. Innov. 19 (8), 697-734.

Cainelli, G., De Marchi, V., Grandinetti, R., 2015. Does the development of environmental innovation require different resources? Evidence from Spanish manufacturing firms. J. Clean. Prod. 94 (1), 211-220.

Calel, R., Dechezlepretre, A., 2016. Environmental policy and directed technological change: evidence from the European carbon market. Rev. Econ. Stat. 98 (1), 173-191.

Caloghirou, Y., Vonortas, N.S., Tsakanikas, A., 2001. University-industry cooperation in the context of the European Framework programmes. J. Technol. Transfer 26 (1-2), 153-161.

Cameron, A.C., Trivedi, P.K., 2013. Regression analysis of count data. Econometri Society Monograph No. 53, 2nd ed. Cambridge University Press, New York.

Cantner, U., Graf, H., Herrmann, J., Kalthaus, M., 2016. Inventor networks in renewable energies: the influence of the policy mix in Germany. Res. Policy 45 (6), 1165-1184.

Carraro, C., De Cian, E., Nicita, L., Massetti, E., Verdolini, E., 2010. Environmental policy and technical change: a survey. Int. Rev. Environ. Res. Econ. 4 (2), 163-219.

Carrillo Hermosilla, J., del Río, P., Könnola, T., 2009. Eco-innovation. When Sustainability and Competitiveness Shake Hands. Palgrave, London.

Castellacci, F., Natera, J.M., 2013. The dynamics of national innovation systems: a panel cointegration analysis of the coevolution between innovative capability and absorptive capacity. Res. Policy 42 (3), 579-594.

Chesbrough, H., Vanhaverbeke, W., West, J., 2006. Open Innovation: Researching a New Paradigm. Oxford University Press, London.

Chesbrough, H., 2003. Open Innovation: The New Imperative for Creating and Profiting from Technology. Harvard Business Press, Boston.

Consoli, D., Marin, G., Marzucchi, A., Vona, F., 2016. Do green jobs differ from non-green jobs in terms of skills and human capital? Res. Policy 45 (5), 1046-1060.

Costantini, V., Crespi, F., Martini, C., Pennacchio, L., 2015. Demand-pull and technologypush public support for eco-innovation: the case of the biofuels sector. Res. Policy 44, $577-595$.

Costantini, V., Crespi, F., Palma, A., 2017. Characterizing the policy mix and its impact on eco-innovation: a patent analysis of energy-efficient technologies. Res. Policy 46 (4), 799-819.

De Marchi, V., Grandinetti, R., 2013. Knowledge strategies for environmental innovations: the case of Italian manufacturing firms. J. Knowl. Manag. 17 (4), 569-582.

De Marchi, V., 2012. Environmental innovation and R\&D cooperation: empirical evidence from Spanish manufacturing firms. Res. Policy 41 (3), 614-623.

Dechezlepretre, A., Sato, M., 2017. The impacts of environmental regulations on competitiveness. Rev. Environ. Econ. Policy 11 (2), 183-220.
Dernis, H., Guellec, D., van Pottelsberghe de la Potterie, B., 2001. Using patent counts for cross-country comparisons of technology output. STI Rev. 27, 129-146.

Di Cagno, D., Fabrizi, A., Meliciani, V., 2014. The impact of participation in European joint research projects on knowledge creation and economic growth. J. Technol. Transfer 39 (6), 836-858.

Di Cagno, D., Fabrizi, A., Meliciani, V., Wanzenbock, I., 2016. The impact of relational spillovers from joint research projects on knowledge creation across European regions. Technol. Forecast. Soc. 108, 83-94.

Dixit, A.K., Pindyck, R.S., 1994. Investment Under Uncertainty. Princeton University Press, Princeton.

Driesen, D., 2005. Economic instruments for sustainable development. In: Wood, S., Richardson, B. (Eds.), Environmental Law for Sustainability: A Critical Reader. Hart Publishing, Oxford, pp. 277-308.

European Commission, 2008. Ex-Post Impact Assessment FP6 Sub-Priority Global Change and Ecosystems, Final Report. Office for Official Publications of the European Communities, Luxembourg.

European Commission, 2010. The Impact of European Policy on the Development of the ERA in the Areas Relevant to Environment, Finale Report. Office for Official Publications of the European Communities, Luxembourg.

Fabrizi, A., Guarini, G., Meliciani, V., 2016. Public knowledge partnerships in European research projects and knowledge creation across R\&D institutional sectors. Technol. Anal. Strateg. 28 (9), 1056-1072.

Fagerberg, J., Srholec, M., 2008. National innovation systems, capabilities and economic development. Res. Policy 37 (9), 1417-1435.

Flanagan, K., Uyarraa, E., Laranja, M., 2011. Reconceptualising the 'policy mix' for innovation. Res. Policy 40 (5), 702-713.

Foray, D., Lissoni, F., 2010. University research and public-private interaction. In: Hall, B.H., Rosenberg, N. (Eds.), Handbook of Economics of Innovation. North Holland/ Elsevier, Oxford, pp. 275-314.

Furman, J.L., Porter, M.E., Stern, S., 2002. The determinants of national innovative capacity. Res. Policy 31 (6), 899-933.

Ghisetti, G., Pontoni, F., 2015. Investigating policy and R\&D effects on environmental innovation: a meta-analysis. Ecol. Econ. 118, 57-66.

Ghisetti, G., Marzucchi, A., Montresor, S., 2015. The open eco-innovation mode. An empirical investigation of eleven European countries. Res. Policy 44 (5), 1080-1093.

Grabher, G., Powell, W.W. (Eds.), 2004. Critical Studies of Economic Institutions: Networks. Edward Elgar, Cheltenham.

Griliches, Z., 1979. Issue in assessing the contribution of research and development to productivity growth. Bell J. Econ. 10 (1), 92-116.

Griliches, Z., 1990. Patents statistics as economic indicators: a survey. J. Econ. Lit. 28 (4), 1661-1707.

Guarini, G., 2015. Complementarity between environmental efficiency and labour productivity in a cumulative growth process. PSL Quart. Rev. 68 (272), 41-56.

Guerzoni, M., Raiteri, E., 2015. Demand-side vs. supply-side technology policies: hidden treatment and new empirical evidence on the policy mix. Res. Policy 44 (3), 726-747.

Haščič, I., Migotto, M., 2015. Measuring Environmental Innovation Using Patent Data: Policy Relevance. OECD Working Party on Environmental Information 6. OECD Publishing.

Hall, B.H., Griliches, Z., Hausman, J.A., 1986. Patents and R\& D: is there a lag? Int. Econ. Rev. 27 (2), 265-302.

Hausman, J., Hall, B., Griliches, Z., 1984. Econometric models for count data and an application to the patents-R\&D relationship. Econometrica 52 (4), 909-938.

Hicks, J.R., 1932. The Theory of Wages. Palgrave MacMillan, Basingstoke.

Hoekman, J., Scherngell, T., Frenken, K., Tijssen, R., 2013. Acquisition of European research funds and its effect on international scientific collaboration. J. Econ. Geogr. 13 (1), 23-52.

Hoglund Isaksson, L., 2005. Abatement costs in response to the Swedish charge on nitrogen oxide emissions. J. Env. Econ. Manag. 50 (1), 102-120.

Horbach, J., Oltra, V., Belin, J., 2013. Determinants and specificities of eco-innovations. An econometric analysis for the French and German Industry based on the Community Innovation Survey. Ind. Innov. 20 (6), 523-543.

Horbach, J., 2008. Determinants of environmental innovation - new evidence from german panel data sources. Res. Policy 37 (1), 163-173.

Jaffe, A.B., Palmer, K., 1997. Environmental regulation and innovation: a panel data study. Rev. Econ. Stat. 79 (4), 610-619.

Jaffe, A.B., Stavins, R.N., 1995. Dynamic incentives of environmental regulation: the effects of alternative policy instruments on technology diffusion. J. Environ. Econ. Manag. 29 (3), 43-63.

Jaffe, A.B., Peterson, S.R., Portney, P.R., Stavins, R.N., 1995. Environmental regulation and the competitiveness of U.S. manufacturing: what does the evidence tell us? J. Econ. Lit. 33 (1), 132-163.

Jaffe, A., Newell, R., Stavins, R., 2003. Technological change and the environment. In: Maler, K.G., Vincent, J.R. (Eds.), Handbook of Environmental Economics. Elsevier, Amsterdam, pp. 461-516.

Jaffe, A.B., Newell, R.G., Stavins, R.N., 2005. A tale of two market failures: technology and environmental policy. Ecol. Econ. 54 (2-3), 164-174.

Jensen, M.B., Johnson, B., Lorenz, E., Lundvall, B.A., 2007. Forms of knowledge and modes of innovation. Res. Policy 36 (5), 680-693.

Johnstone, N., Labonne, J., 2006. Environmental policy, management and Research and Development in OECD. Econ. Stud. 42 (1), 169-203.

Johnstone, N., Labonne, J., Thevenot, C., 2008. Environmental policy and economies of scope in facility-level environmental practices. Environ. Econ. Pol. Stud. 9 (3), 145-166.

Johnstone, N., Hašcic, I., Popp, D., 2010a. Renewable energy policies and technological innovation: evidence based on patent counts. Environ. Resour. Econ. 45 (1), 133-155. 
Johnstone, N., Hašcic, I., Kalamova, M., 2010b. Environmental policy characteristics and technological innovation. Econ. Polit. 27 (2), 275-299.

Kammerer, D., 2009. The effects of customer benefit and regulation on environmental product innovation. Empirical evidence from appliance manufacturers in Germany. Ecol. Econ. 68 (8-9), 2285-2295.

Karaca Mandic, P., Norton, E.C., Dowd, B., 2012. Interaction terms in nonlinear models. Health Serv. Res. 47 (1), 255-274.

Koźluk, T., Zipperer, V., 2014. Environmental policies and productivity growth: a critical review of empirical findings. OECD Econ. Stud. 1 (1), 155-185.

Lanjouw, J.O., Mody, A., 1996. Innovation and the international diffusion of environmentally responsive technology. Res. Policy 25 (4), 549-571.

Lanoie, P., Laurent Lucchetti, J., Johnstone, N., Ambec, S., 2011. Environmental policy, innovation and performance: new insights on the porter hypothesis. J. Econ. Manage. Strat. 20 (3), 803-842.

Lehmann, P., 2012. Justifying a policy mix for pollution control: a review of economic literature. J. Econ. Surv. 26 (1), 71-97.

Luukkonen, T., 2000. Additionality of EU framework programmes. Res. Policy 29, $711-724$.

Luukkonen, T., 2002. Technology and market orientation in company participation in the EU framework programme. Res. Policy 31 (3), 437-455.

Maggioni, M.A., Nosvelli, M., Uberti, T.E., 2007. Space versus networks in the geography of innovation: a European analysis. Pap. Reg. Sci. 86 (3), 271-293.

Mancinelli, S., Mazzanti, M., 2009. Innovation, networking and complementarity: evidence on SME performances for a local economic system in North-Eastern Italy. Ann. Reg. Sci. 43 (3), 567-597.

Marzucchi, A., Montresor, S., 2017. Forms of knowledge and eco-innovation modes: evidence from Spanish manufacturing firms. Ecol. Econ. 131, 208-221.

Mazzanti, M., Zoboli, R., 2008. Complementarities, firm strategies and environmental innovations: empirical evidence for a district based manufacturing system. Environ. Sci. 5 (1), 17-40.

Menanteau, P., Finon, D., Lamy, M.L., 2003. Prices versus quantities: choosing policies for promoting the development of renewable energy. Energy Policy 31 (8), 799-812.

Millock, K., Nauges, C., Sterner, T., 2004. Environmental Taxes: A Comparison of French and Swedish Experience from Taxes on Industrial Air Pollution. CESifo DICE Report.

Morales Lage, R., Bengochea Morancho, A., Martínez Zarzoso, I., 2016. Does Environmental Policy Stringency Foster Innovation and Productivity in Oecd Countries? Cege Discussion Papers No. 282, April.

Nagaoka, S., Motohashi, K., Goto, A., 2010. Patent statistics as an innovation indicator. In: Hall, B.H., Rosenberg, N. (Eds.), Handbook of Economics of Innovation. North Holland/Elsevier, Oxford, pp. 1083-1127.

Ostrom, E., Burger, J., Field, C.B., Norgaard, R.B., Policansky, D., 1999. Revisiting the commons: local lessons, global challenges. Science 284, 278-282.

Ostrom, E., 2005. Understanding Institutional Diversity. Princeton University Press, Cambridge.

Paavola, J., 2007. Institutions and environmental governance: a reconceptualization. Ecol. Econ 63 (1), 93-103.

Paier, M., Scherngell, T., 2011. Determinants of collaboration in european R\&D networks: empirical evidence from a discrete choice model. Ind. Innov. 18 (1), 89-104.

Pindyck, R.S., 2007. Uncertainty in environmental economics. Rev. Environ. Econ. Policy 1 (1), 45-65

Popp, D., Newell, R., Jaffe, A., 2010. Energy, the environment, and technological change. In: Hall, B.H., Rosenberg, N. (Eds.), Handbook of the Economics of Innovation. Elsevier, Amsterdam, pp. 873-937.

Popp, D., 2002. Induced innovation and energy prices. Am. Econ. Rev. 92 (1), 160-180.
Popp, D., 2003. Pollution control innovations and the clean air act of 1990. J. Policy Anal. Manag. 22 (4), 641-660.

Popp, D., 2006. International innovation and diffusion of air pollution control technol ogies: the effects of NOx and SO2 regulation in the US, Japan and Germany. J. Environ. Econ. Manag. 51 (1), 46-71.

Porter, M.E., Van der Linde, C., 1995. Toward a new conception of the environment-competitiveness relationship. J. Econ. Perspect. 9 (4), 97-118.

Powell, W.W., Grodal, S., 2006. Networks of innovators. In: Fagerberg, J., Mowery, D.C. (Eds.), The Oxford Handbook of Innovation. Oxford University Press, Oxford, pp. $56-85$.

Rehfeld, K.M., Rennings, K., Ziegler, A., 2007. Integrated product policy and environmental product innovations: an empirical analysis. Ecol. Econ. 61 (1), 91-100.

Rennings, K., et al., 2006. The influence of different characteristics of the EU environmental management and auditing scheme on technical environmental innovations and economic performance. Ecol. Econ. 57 (1), 45-59.

Rennings, K., 2000. Redefining innovation -Eco-Innovation research and the contribution from ecological economics. Ecol. Econ. 32 (2), 319-332.

Rogge, K.S., Reichardt, K., 2016. Policy mixes for sustainability transitions: an extended concept and framework for analysis. Res. Policy 45 (8), 1620-1635.

Rothaermel, F.T., Agung, S.H., Jiang, L., 2007. University entrepreneurship: a taxonomy of the literature. Ind. Corp. Change 16 (4), 691-791.

Rubashkina, Y., Galeotti, M., Verdolini, E., 2015. Environmental regulation and competitiveness: empirical evidence on the porter hypothesis from European manufacturing sectors. Energy Policy 83 (8), 288-300.

Söderholm, P., Ek, K., Pettersson, M., 2007. Wind power development in Sweden: global policies and local obstacles. Renew. Sustain. Energy Rev. 11 (3), 365-400.

Schmidt, T.S., Schneider, M., Rogge, K.S., Schuetz, M.J.A., Hoffmann, V.O., 2012. The effects of climate policy on the rate and direction of innovation: a survey of the EU ETS and the electricity sector. Environ. Innov. Soc. Transit. 2, 23-48.

Squicciarini, M., Dernis, H., Criscuolo, C., 2013. Measuring Patent Quality: Indicators of Technological and Economic Value. OECD Science. Technology and Industry Working Papers 2013/3. OECD.

Taylor, M.R., 2012. Innovation under cap-and-trade programs. Proc. Natl. Acad. Sci. U. S. A. 109 (13), 4804-4809.

Triguero, A., Moreno Mondéjar, L., Davia, M.A., 2013. Drivers of different types of ecoinnovation in European SMEs. Ecol. Econ. 92, 25-33.

Unruh, G.C., 2000. Understanding carbon lock-in. Energy Policy 28 (12), 817-830.

Varsakelis, N., 2006. Education, political institutions and innovative activity: a crosscountry empirical investigation. Res. Policy 35 (7), 1083-1090.

Vega Jurado, J., Gutiérrez-Gracia, A., Fernández-de-Lucio, I., Manjarrés-Henríquez, L., 2008. Analyzing the determinants of firm's absorptive capacity: beyond R\&D. R\&D Manage 38 (4), 392-405.

Vona, F., Marin, G., Consoli, D., Popp, D., 2015. Green Skills. NBER No. 19951.

Wagner, M., 2007. On the relationship between environmental management, environmental innovation and patenting: evidence from German manufacturing firms. Res. Policy 36 (10), 1587-1602.

Wang, N., Hagedoorn, J., 2014. The lag structure of the relationship between patenting and internal R\&D revisited. Res. Policy 43 (8), 1275-1285.

Ziegler, A., Nogareda, J.S., 2009. Environmental management systems and technological environmental innovations: exploring the causal relationship. Res. Policy 38 (5), 885-893.

Ziegler, A., Rennings, K., 2004. Determinants of environmental innovations in Germany: do organizational measures matter? A discrete choice analysis at the firm level. ZEW Discussion Papers No. 04-30. 